\section{2}

EXPERIMENTAL STUDY OF HYDROGEN FORMATION AND RECOMBINATION UNDER POSTULATED LMFBR ACCIDENT CONDITIONS

\begin{tabular}{|c|c|c|}
\hline $\begin{array}{l}\text { perated by the } \\
\text { Westinghouse } \\
\text { Hanford Company }\end{array}$ & 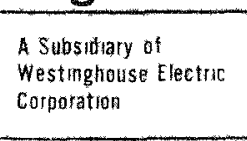 & 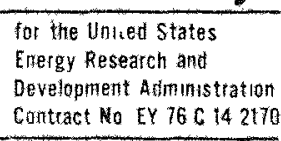 \\
\hline
\end{tabular}




\section{DISCLAIMER}

This report was prepared as an account of work sponsored by an agency of the United States Government. Neither the United States Government nor any agency Thereof, nor any of their employees, makes any warranty, express or implied, or assumes any legal liability or responsibility for the accuracy, completeness, or usefulness of any information, apparatus, product, or process disclosed, or represents that its use would not infringe privately owned rights. Reference herein to any specific commercial product, process, or service by trade name, trademark, manufacturer, or otherwise does not necessarily constitute or imply its endorsement, recommendation, or favoring by the United States Government or any agency thereof. The views and opinions of authors expressed herein do not necessarily state or reflect those of the United States Government or any agency thereof. 


\section{DISCLAIMER}

Portions of this document may be illegible in electronic image products. Images are produced from the best available original document. 


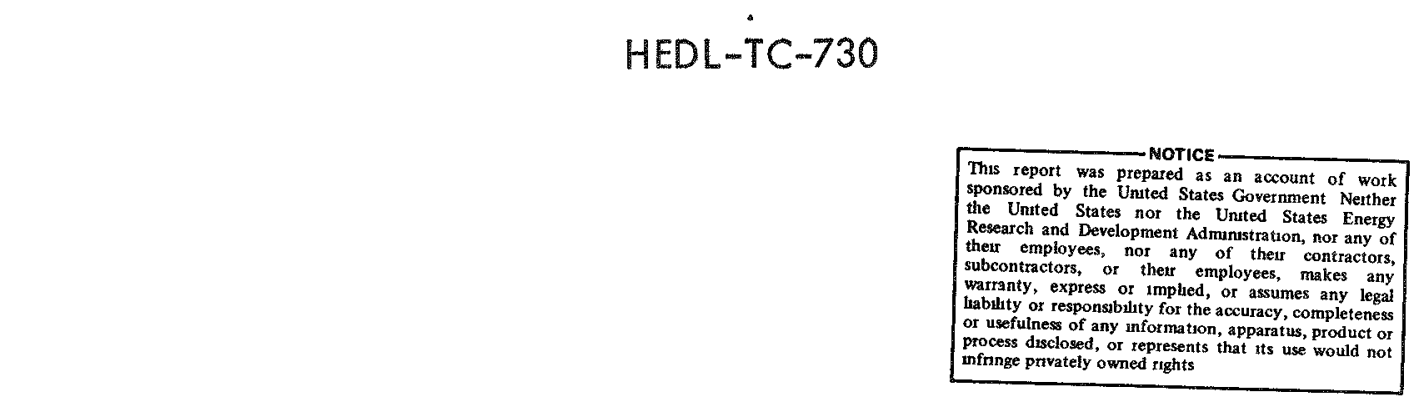

\section{EXPERIMENTAL STUDY OF HYDROGEN} FORMATION AND RECOMBINATION

UNDER POSTULATED LMFBR ACCIDENT CONDITIONS

by

R.W. Wierman

R.K. Hilliard

December 1, 1976

\begin{tabular}{|c|c|c|}
\hline $\begin{array}{l}\text { Operated by the } \\
\text { Westinghouse } \\
\text { Hanford Company }\end{array}$ & $\begin{array}{l}\text { A Substitiary of } \\
\text { Westinghouse Electric } \\
\text { Corporation }\end{array}$ & $\begin{array}{l}\text { for the United States } \\
\text { Energy Research and } \\
\text { Development Administration } \\
\text { Contract No EY } 76 \text { C } 142770\end{array}$ \\
\hline
\end{tabular}


HEDL-TC-730

\title{
EXPERIMENTAL STUDY OF HYDROGEN FORMATION AND RECOMBINATION UNDER POSTULATED LMFBR ACCIDENT CONDITIONS
}

\begin{abstract}
R.W. Wierman, R.K. Hilliard
This report describes an experimental study of hydrogen jets buming in air, hydrogen formation by sodium in humid air atmospheres, and the effects of nitrogen, water vapor, sodium vapor/aerosol, jet velocity, and jet temperature on ignition of hydrogen jets. The results show that hydrogen jets above $1450^{\circ} \mathrm{F}\left(788^{\circ} \mathrm{C}\right)$ issuing into an air atmosphere need no ignition source for ignition, a hydrogen jet temperature highex than $500^{\circ} \mathrm{F}\left(260^{\circ} \mathrm{C}\right)$ and containing more than six groms of sodium per cubie meter of jet gas will auto-ignite in an air atmosphere, the burning efficiency of a hydrogen jet decreases rapidly to zero when the oxygen concentration outside the flame region approaches 10 percent, and hydrogen does not form from a sodium-nitrogen jet issuing into a humid air atmosphere until the ratio $\mathrm{O}_{2} /\left(\mathrm{H}_{2} \mathrm{O}_{2} \mathrm{O}_{2}\right)$ is less than 0.5 .
\end{abstract}


$$
\text { . }
$$ 


\section{CONTENTS}

Page

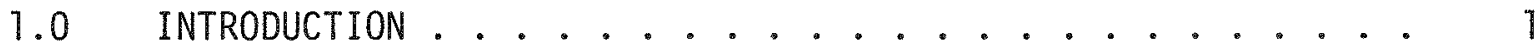

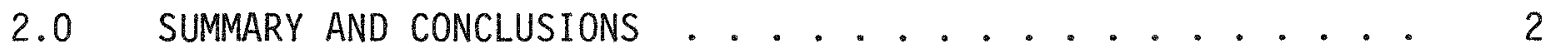

3.0 DESCRIPTION OF TEST EQUIPMENT ..................... 3

3.1 Test Facility . . . . . . . . . . . . . . 3

3.2 Test Apparatus. . . . . . . . . . . . . . 3

3.3 Instrumentation .............. 8

4.0 RESULTS AND EVALUATIONS ........................ 9

4.1 Scoping Tests ................. 10

4.2 Test Series A - Ignition of Hydrogen-Nitrogen Jets . . 13

4.3 Test Series B - Ignition of Hydrogen-Nitrogen-Sodium

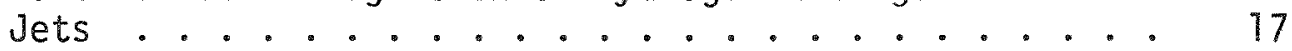

4.4 Test Series C - Ignition of Hydrogen-Nitrogen-SodiumWater Jets ............. 23

4.5 Test Series D - Effects of Oxygen Depletion on Hydrogen Burning .............. 24

4.6 Test Series $E$ - Hydrogen Formation in Sodium-Water Air Atmospheres.............. 30

4.7 Test Series F - Effects of Jet Velocity ....... 33

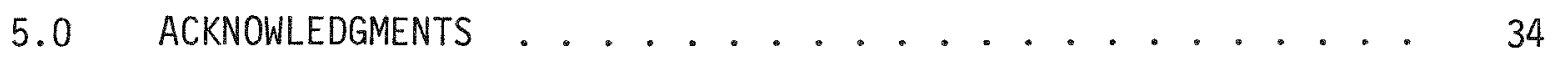

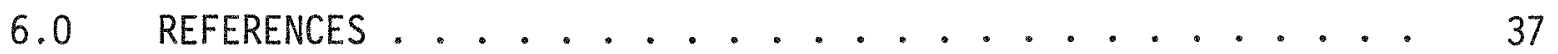

APPENDIX A - Test Equipment ........... A-1

APPENDIX B - Scoping Tests Results........... B-1 
$$
\text { . }
$$ 


\section{TABLES}

Table

Page

1 Accuracies of Reported Data . . . . . . . . . 9

2 Test Conditions for Hydrogen Formation and

Recombination Tests ............ 14

3 Hydrogen Ignition Percentage (IP) as a Function of Jet Gas Temperature .............. 15

4 Test Measurements for Test Series E . . . . . . . 32

5 Jet Velocities and Reynolds Numbers for $75 \%$ Hydrogen$25 \%$ Nitrogen Jets ............. . . 35

A-1 Thermocouple Locations . . . . . . . . . . A A-5 
$$
\text { . }
$$ 


\section{FIGURES}

Figure

Page

1 Large Sodium Fire Facility . . . . . . . . . . . 4

2 Test Cell Arrangement ................ 5

3 Test Vessel Details . . . . . . . . . . . 6

$4 \quad$ Thermocouple and Hot Wire Igniter Positioning Over Vent Nozzle..................

5 Ignition of a Hydrogen-Nitrogen Jet (Without Sodium Aerosol) as a Function of Temperature........

6 Time History Illustrating Hydrogen Jet Burning Characteristics and Origin of $1450^{\circ} \mathrm{F}$ Auto-Ignition Temperature Limit ................ . . . 18

7 Conservative Limits for Hydrogen-Sodium Jet Ignition . . . . 20

8 Ignition Characteristics of a Hydrogen-Sodium Jet . . . . 22

9 Effect of Oxygen Depletion on Hydrogen Burning Efficiency of a Hydrogen-Nitrogen-Sodium Jet . . . . . . 26

10 Effect of Oxygen Depletion on Hydrogen Burning Efficiency of a Hydrogen-Nitrogen Jet (Without Sodium Aerosol) ....

11 Effect of 0xygen Depletion on Hydrogen Burning Efficiency of a Hydrogen-Nitrogen Jet at a Higher Velocity ......

12 Hydrogen Burning Efficiency of a Hydrogen-Nitrogen-Sodium Jet as a Function of the Supplied and Exhausted Oxygen

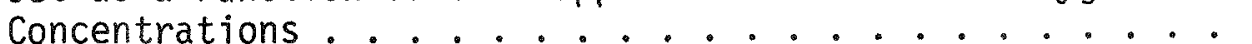

13 Hydrogen Formation in Sodium-Humid Nitrogen-Oxygen Atmospheres ..................

14 Ignition Characteristics of a Turbulent Hydrogen-Sodium Jet .........................

A-la Schematic of Heater and Thermocouple Locations - Primary Vessel Walls...................

A-1b Schematic of Heater and Thermocouple Locations - Secondary Vessel walls

A-1c Schematic of Heater and Thermocouple Locations - Bottom of Primary Vessel and Diaphragm .......... A-4

A-2 One-Quarter Front View of Completed Installation of Test Vessels. 
$$
\text { . }
$$ 


\section{FIGURES (Cont'd.)}

Figure Page

A-3 External Sodium Vapor/Aerosol Generator . . . . . . A-7

A-4 Schematic of Steam Generator . . . . . . . . . . A-8

A-5 Schematic of Gas Humidifier and Drier. . . . . ... A-9

A-6 Schematic of 0.43 -Inch ID Nozzle and Thermocouple Arrangement ............. A-10

B-1 Hydrogen Ignition Percentage Determination by Temperature Method ................. B $\mathrm{B}-2$

B-2 Hydrogen Ignition Percentage Determination by Secondary Hydrogen Method ................ B-3

B-3 Effects of Nozzle Diameter on Hydrogen Ignition. . . . . B-4 
EXPERIMENTAL STUDY OF HYDROGEN FORMATION AND RECOMBINATION UNDER POSTULATED LMFBR ACCIDENT CONDITIONS

\subsection{INTRODUCTION}

Hydrogen generated in the reactor cavity during a hypothetical LMFBR reactor vessel melt-through accident may be released to the air atmosphere within the Reactor Containment Building (RCB). During a large sodium fire test (FT) at the Hanford Engineering Development Laboratory (HEDL), (1) it was noted that the sodium-hydrogen mixture released from an oxygen-free space into a normal air environment ignited and burned even though the gas temperature was far below the handbook value for auto-ignition $\left(1085^{\circ} \mathrm{F}, 585^{\circ} \mathrm{C}\right)$. (2) This phenomenon was attributed to the presence of sodium aerosol particles which acted as an ignition source. If hydrogen self-ignites as it enters the air atmosphere in the head compartment or Reactor Containment Building (RCB), it would not accumulate in the RCB and thus the integrity of the RCB would not be threatened by hydrogen accumulation.

Therefore, an experimental investigation was initiated to study the phenomena associated with the formation and recombination of hydrogen under conditions similar to those postulated for LMFBR vessel melt-through accidents. Two hypothetical accident cases were considered:

1. The reactor cavity liner fails, allowing steam released from concrete to enter the reactor cavity, either directly into the sodium pool or into the gaseous atmosphere above the sodium surface. In either case, the water vapor reacts with sodium to form hydrogen and $\mathrm{Na}_{2} \mathrm{O}$. The reactor cavity atmosphere, containing variable amounts of hydrogen, nitrogen, water vapor, sodium vapor, and aerosol particles $\left(\mathrm{Na}_{2} \mathrm{O}, \mathrm{Na}\right)$, is vented to the RCB air atmosphere via some undefined or designed leak path.

2. The reactor cavity liner does not fail. No water enters the reactor cavity. The reactor cavity atmosphere, containing only nitrogen, sodium vapor, and sodium aerosol particles, is vented to the RCB 
via a separate vent pipe. In addition, water vapor is released from the concrete floor of the RCB directly to the RCB atmosphere. Hydrogen may be formed in the RCB atmosphere if the sodium vapor or aerosol reacts with the water vapor.

In the experimental study, these postulated accident conditions were simulated by jetting various mixtures of hydrogen, nitrogen, water vapor, and sodium vapor/aerosol into an air atmosphere. The oxygen and water vapor content of the air atmosphere was also varied. The experimental details and results are discussed in the following sections of this report.

\subsection{SUMMARY AND CONCLUSIONS}

Eighteen tests were performed in the HEDL Large Sodium Fire Facility (LSFF) from March 17, 1976 to October 8, 1976.

These tests, involving hydrogen recombination (ignition) and formation, were divided into six series:

- Test Series A - Ignition of Hydrogen-Nitrogen Jets

- Test Series B - Ignition of Hydrogen-Nitrogen-Sodium Jets

- Test Series C - Ignition of Hydrogen-Nitrogen-Sodium-Water Jets

- Test Series D - Effects of Oxygen Depletion on Hydrogen Burning

- Test Series E - Hydrogen Formation in Sodium-Water-Air Atmospheres

- Test Series F - Effects of Jet Velocity

The conclusions and observations are summarized below:

- Ignition of a hydrogen-nitrogen jet discharged into ajr always occurred when the sodium concentration in the jet was greater than $6 \mathrm{~g} / \mathrm{m}^{3}$ and the jet temperature was greater than $500^{\circ} \mathrm{F}\left(260^{\circ} \mathrm{C}\right)$. Hydrogen ignition often occurred at lower sodium concentrations and lower gas temperatures, but ignition was of an unreliable nature for the lower conditions. Large (greater than 100-um diameter) sodium particles were attributed as the source of many of these ignitions. Once the hycirogen jet was janited, it burned continuously, similar to a Bunsen burner.

- Large amounts of water vapor carried by the sodium-hydrogen (70:1 mole ratio of water to sodium) jet did not significantly affect hydrogen ignition. 
- The ignition of a hydrogen-nitrogen jet discharged into air is greatly dependent on the temperature of the jet gas. The lower flammability limit (percent hydrogen) decreases from $12 \%$ hydrogen at $100^{\circ} \mathrm{F}\left(38^{\circ} \mathrm{C}\right)$ to $2 \%$ hydrogen at $1500^{\circ} \mathrm{F}\left(816^{\circ} \mathrm{C}\right)$. When the temperature in a hydrogen-nitrogen jet exceeds $1450^{\circ} \mathrm{F}\left(788^{\circ} \mathrm{C}\right)$ no ignition source is needed for combustion.

- Hydrogen jet velocities less than the "blowoff velocity" have no significant effect on hydrogen jet ignition.

- A hydrogen jet discharged into normal air burns with essentially 100 percent efficiency. However, the burning efficiency drops rapidly to zero when the oxygen concentration in the air outside of the flame region decreases to approximately 10 percent.

- Sodium vapor and aerosol carried by a nitrogen jet into a humid nitrogenoxygen atmosphere did not form hydrogen until the ratio $\mathrm{O}_{2} /\left(\mathrm{H}_{2} \mathrm{O}+\mathrm{O}_{2}\right)$ was less than 0.5 .

\subsection{DESCRIPTION OF TEST EQUIPMENT}

\subsection{Test Facility}

The tests were performed in the HEDL Large Sodium Fire Facility. A plan view of the facility is shown in Figure 1. The tests were performed within a $2500 \mathrm{ft}^{3}$ $\left(71 \mathrm{~m}^{3}\right)$ cell which contained a normal air atmosphere. During testing, the ce11 containing the test apparatus was ventilated at a rate of 500 CFM $\left(0.24 \mathrm{~m}^{3} / \mathrm{sec}\right)$ of air which was scrubbed, filtered, and discharged to a 250-foot (76-m) high stack.

\subsection{Test Apparatus}

Details of the test apparatus are shown in Figures 2 and 3. The primary vessel, representing the reactor cavity, and the secondary vessel, representing the reactor head compartment or RCB, were constructed of $16-\mathrm{in}$. (0.41-m) diameter 304 stainless steel pipe with $3 / 16-i n$. $(4.8-\mathrm{mm})$ walls. Each vessel was 30 inches $(0.76 \mathrm{~m})$ high and had a volume of $3.5 \mathrm{ft}^{3}\left(0.1 \mathrm{~m}^{3}\right)$. The primary vessel had a solid bottom 


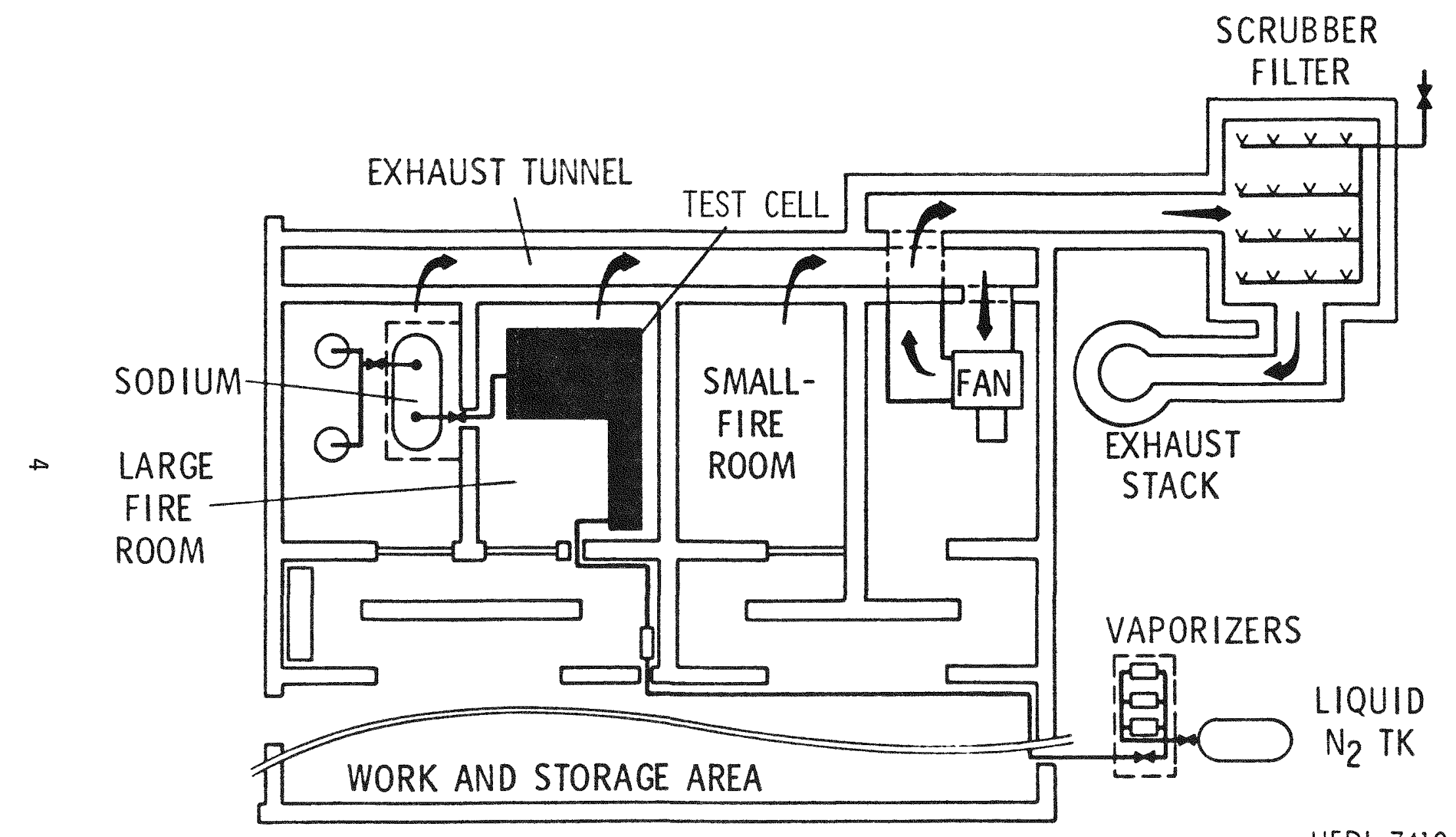

HEDL 7410-61

FIGURE 1. Large Sodium Fire Facility. 


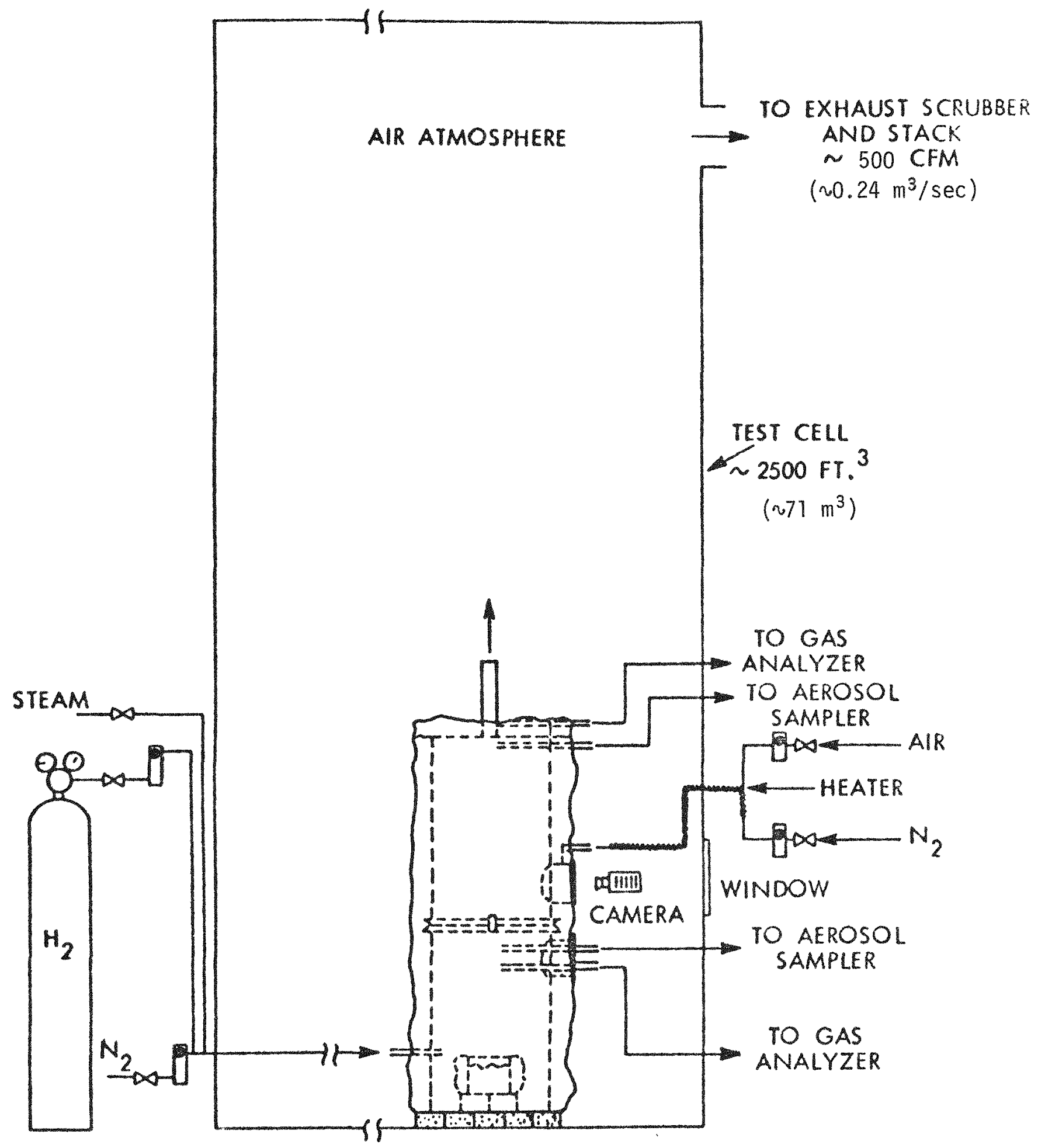

HEDL $7602-49.2$

FIGURE 2. Test Ce11 Arrangement. 


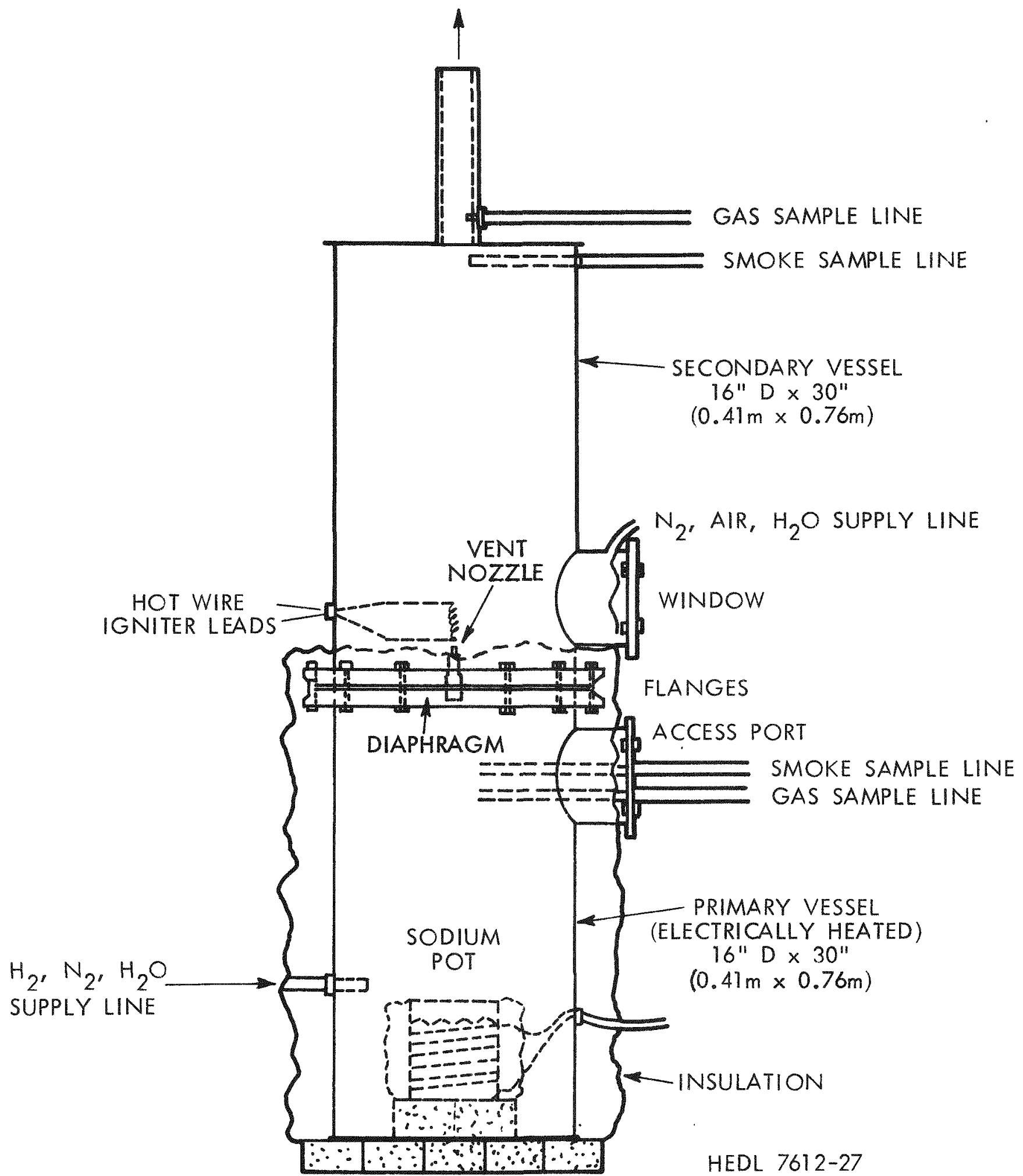

FIGURE 3. Test Vessel Details. 
and contained several penetrations. The secondary vessel, located above the primary vessel, had a loose-fitting lid and several penetrations, including a 6 -inch $(0.15-\mathrm{m})$ diameter nozzle equipped with a window. Both vessels were wrapped with heaters and insulation, and had several thermocouple locations (see Appendix $A$, Figures $A-1$ and $A-2$ ).

A 3/16-inch (4.8-mm) thick stainless steel diaphragm separated the two vessels and contained a pipe coupling at the centerline. The coupling permitted the installation of nozzles of various sizes and types of material which simulated a leakage path from the reactor cavity. The diaphragm also had heaters, insulation, and thermocouples.

Each vessel had its own gas supply. $\mathrm{H}_{2}$ and $\mathrm{N}_{2}$, each with flow capabilities of 0 to 2 SCFM $(57 \mathrm{l} / \mathrm{min}$ at STP) were supplied to the primary vessel. Air up to 4 SCFM ( $113 \mathrm{l} / \mathrm{min}$ at STP) and $\mathrm{N}_{2}$ up to 2 SCFM $(57 \mathrm{l} / \mathrm{min}$ at STP) could be supplied to the secondary vessel. All gas flows were measured by rotameters.

Two methods of generating sodium vapor and aerosol for the primary vessel were used. Initially, the system was as shown in Figure 3. A 6-inch (0.15-m) diameter by 9 -inch $(0.23-\mathrm{m})$ high stainless steel beaker wrapped with heaters and containing approximately $41 \mathrm{bs}(1.8 \mathrm{~kg})$ of sodium was heated in the primary vessel. After Test Series D, an external sodium aerosol generator was welded to the side of the primary vessel (see Figure $A-3$ ). In both cases, the primary gas swept across the sodium surface. No differences in aerosol characteristics between the two types of generators were noticed.

Two steam generators were used to inject steam into each vessel. Each of the identical steam generators consisted of a 100-mi burette that dripped distilled water into a heated $2-$ inch by 8 -inch $(5-\mathrm{cm}$ by $20-\mathrm{cm})$ stainless steel bottle that fed into a heated gas supply line (see Figure A-4).

Valved into the secondary vessel gas supply line was a variable temperature humidifier and a drying column (see Figure A-5). The humidifier consisted of a 3 -ft $(0.9-\mathrm{m})$ section of 2 -inch $(5-\mathrm{cm})$ stainless steel pipe filled with gravel and water. For temperature control, the pipe was wrapped with heating cable and insulation. The secondary supply gas was allowed to bubble upward through the column. The drying column consisted of another 3-ft $(0.9-\mathrm{m})$ section of 2-inch $(5-\mathrm{cm})$ stainless steel pipe filled with a chemical drying agent. 


\subsection{Instrumentation}

The gases in the primary and secondary vessels were monitored continuously by on-line gas analyzers. The gas sample flow from each vessel was 0.05 SCFM $(1.4 \mathrm{l} / \mathrm{min}$ at STP), which was split into one-third of the flow going to the oxygen meters and the other two-thirds to the hydrogen meters. The oxygen concentration of both the primary and secondary vessels was determined by oxygen analyzers. (a) A thermal conductivity cel ${ }^{(b)}$ analyzed the primary hydrogen concentration while a gas chromatograph $(c)$ and thermal conductivity analyzer (d) were used for determining the secondary hydrogen concentration. Water vapor concentrations in room-temperature gas mixtures were measured by a hygrometer. (e)

A11 temperatures were monitored by Type $K$ (chrome1-alumel) thermocouples. A list of the thermocouples and locations used throughout the tests can be found in Appendix A. Nine of the thermocouples were used with temperature controllers which supplied electrical power to various heaters.

All gas flows, supplying and sampling, were controlled by manual valves and monitored by rotameters. The supplied gases included hydrogen with a minimum purity of $99.5 \%$, nitrogen with a minimum purity of $99.9985 \%$, and normal room air with a nominal $21 \%$ oxygen concentration.

The amount of steam added to the primary and secondary gas supply lines was determined by measuring the amount of water injected into the steam generators. For the secondary gas supply, a humidifier was also used to supply water vapor. A schematic of one of the two identical steam generators and the humidifier is shown in Appendix A. Using the humidifier, the amount of added water vapor was determined by measuring the gas temperature in the humidifier and consulting standard humidity tables.

Sodium vapor and aerosol concentrations in both vessels were determined by filtering a measured amount of vessel gas and then analyzing the filter for total

\footnotetext{
(a) Beckman Model 742, Beckman Instruments, Inc.

(b) Gow-Mac Mode1 TRIIIA, Gow-Mac Co.

(c) Varian Model 920, Varian Instrument Division

(d) Thermatron Mode1 T-3, Mine Safety Appliances Co.

(e) Panametrics Model 1000, Panametrics, Inc.
} 
amount of sodium collected. Two methods of filter analysis were used: (1) flame spectrophotometry and (2) chemical titration. Both methods produced data in close agreement.

Table 1 is a summary of instrument and measurement errors reflected in the test data.

TABLE 1

ACCURACIES OF REPORTED DATA

Instrumented Quantity

Hydrogen flow

Nitrogen flow

Air flow

Primary gas temperature

Secondary gas temperature

Sodium temperature

PV hydrogen

SV hydrogen

PV oxygen

SV oxygen

\section{Calculated Quantity}

Gas flow through nozzle Hydrogen ignition percentage Sodium aerosol concentration
Accuracy

$\pm 5 \%$ of indicated flow

$+5 \%$ of indicated flow

$\pm 2 \%$ of indicated flow

$\pm 3 \%$ of indicated temperature

$\pm 10 \%$ of indicated temperature

$+1 \%$ of indicated temperature

$\pm 1 \%$ hydrogen

$+0.3 \%$ hydrogen*

$+0.3 \%$ oxygen

$+0.5 \%$ oxygen

$* \pm 0.02 \%$ hydrogen for Test Series $D$ and $E$

\subsection{RESULTS AND EVALUATIONS}

The tests were separated into two phases with differing ignition sources. During the first phase, which consisted of Test Series A, a hot wire igniter was used. The igniter wire was removed and a sodium vapor/aerosol generator was added to the primary vessel for the second phase of testing, which began with Test Series B. 


\subsection{Scoping Tests}

Several scoping tests were performed before each phase of testing for the purpose of obtaining a better understanding of the test equipment, test parameters, and methods of analyzing the data.

The first scoping test was to determine the gas sample time lag between the vessels and gas analyzers. The gas within the vessels was sampled for composition by flowing 0.05 SCFM $(1.4 \mathrm{l} / \mathrm{min}$ at STP) to the gas analyzers. The effective time $1 \mathrm{ag}$ was between 1.5 and 2.0 minutes. For a conservative dataanalyzing convention, the time lag was considered to be 2.0 minutes. For normal increasing hydrogen concentration rates, the difference in hydrogen percentage using 1.5 and 2.0 minutes was usually less than 0.5 percent hydrogen.

There were three ways of determining hydrogen ignition during a test: (1) temperature response in the region above the nozzle, (2) hydrogen decrease in the secondary vessel, and (3) visually, if the flame was visible. Of these methods, the temperature response proved to be the most reliable, and the method of hydrogen reduction in the secondary vessel was used as a check. When no sodium was present, the flame was generally invisible for hydrogen concentrations less than 25 percent. The difference between these methods was usualiy less than 1 percent hydrogen.

To determine the hydrogen ignition percentage using the temperatureresponse method, the average temperature-time slopes before ignition and after ignition were determined. The ignition time was determined from the point of intersection of the two lines. Two minutes were then added for the response $\mathrm{lag}$, and the hydrogen percentage determined from the hydrogen recorder chart. Figure B-1 in Appendix B illustrates this procedure. Using the secondary hydrogen concentration method, the ignition percentage was determined by plotting the primary against the secondary hydrogen concentrations. The plot results in a peak where the hydrogen buildup in the secondary vessel began to decrease at the time burning commenced. The primary hydrogen concentration at ignition is determined by this peak. See Figure B-2 for an example of this method.

The effect of varying the nozzle diameter at a constant 0.10 -SCFM $(2.8 \mathrm{l} / \mathrm{min}$ at STP) flowrate through the nozzle was studied. Three nozzles were 
tested: (1) half-inch schedule 40 pipe $(0.622-i n$., or 15.8-mm ID); (2) halfinch tube (0.43-in., or 10.9-mm ID); and (3) three-eighths-inch tube $(0.305-$ in., or $7.75-\mathrm{mm}$ ID). The results of these tests are shown in Figure $B-3$ in Appendix B. It was decided to use the three-eighths-inch tube nozzle on the basis of better clarity of the ignition point and the 0.10 SCFM $(2.8 \mathrm{l} / \mathrm{min}$ at STP) flowrate during Test Series A.

The importance of ignition wire positioning was studied by testing various ignition wire locations. It was found that the vertical positioning was not as important as the horizontal positioning for hydrogen ignition. Figure 4 illustrates the position that gave good ignition characteristics and was used during the first phase of testing.

The presence of the secondary vessel and the effects of air flows from 1.0 to $2.5 \operatorname{SCFM}(28.3$ to $70.8 \mathrm{l} / \mathrm{min})$ on the hydrogen flame and its ignition characteristics were found to be insignificant.

Uniform gas mixing in the primary vessel and secondary vessel (without a flame) was apparent from the gas analys is recordings. Hydrogen injected at a $0.15-$ SCFM (4.2- $/ \mathrm{min}$ at STP) flowrate into the primary vessel previously inerted with nitrogen resulted in a smooth exponential hydrogen concentration increase, indicating no stratification or "gas pockets" in the primary vessel. Likewise, air injected at a 2.0-SCFM (56-l/min at STP) flowrate into the nitrogen-inerted secondary vessel resulted in a smooth oxygen concentration increase. The extent of gas mixing in the secondary vessel with a hydrogen flame present was difficult to determine due to hydrogen and oxygen consumption, but should have been improved by the convection currents induced by the flame.

After sodium was introduced to the primary vessel, metallic sodium and sodium oxide would often accumulate around the nozzle exit and then propagate downward into the nozzle. This would result in an exponential increase of the pressure difference across the nozzle and eventually a plugged nozzle that required a pressure of several psi to clear. A weighted and tapered rod, which could be manually raised and lowered through the nozzle, was mounted in the secondary vessel and controlled from outside of the cell to keep the nozzle unplugged. 

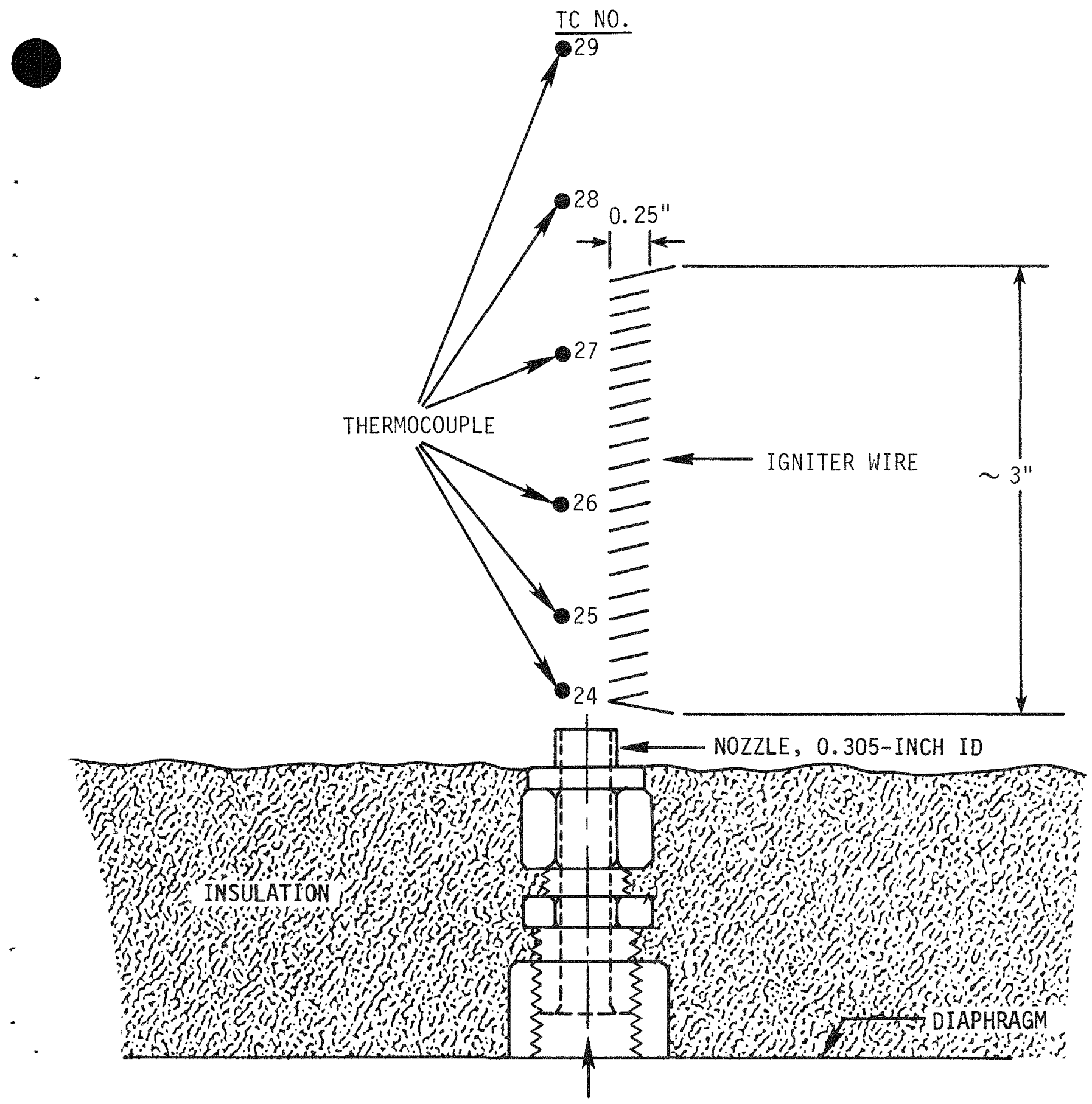

FLOW

(Actual Size)

HEDL $7611-164.7$

FIGURE 4. Thermocouple and Hot Wire Igniter Positioning over Vent Nozzle. 


\subsection{Test Series A - Ignition of Hydrogen-Nitrogen Jets}

The objectives of Test Series A were to: (1) determine the ignition characteristics of a hydrogen-nitrogen jet, and (2) determine the effects of the presence of the secondary vessel on ignition characteristics. The test procedure was to inert the primary vessel with nitrogen and then to vary the hydrogen from 0 to $100 \%$ in the primary vessel at a total supply rate of 0.15 SCFM $(4.25 \ell / \mathrm{min}$ at STP). A continuous 0.05 SCFM $(1.4 \ell / \mathrm{min}$ at STP) gas sample was withdrawn from the primary vessel and the balance of the primary gas $(0.10$ SCFM or $2.85 \mathrm{l} / \mathrm{min})$ flowed through the nozzle to the secondary vesse1. An air purge of 2.0 SCFM $(56.6 \mathrm{l} / \mathrm{min})$ was flowed through the secondary vessel to supply the flame with oxygen and insure against an explosive concentration of hydrogen accumulating. A similar gas sample was taken from the secondary vessel and analyzed. When the primary hydrogen concentration reached about $95 \%$, a 0.50 SCFM $(14.2 \mathrm{l} / \mathrm{min})$ nitrogen purge of the primary vessel was started and continued until the primary hydrogen concentration decreased to less than 1 percent. This procedure was repeated for several primary gas temperatures which were measured by thermocouples in the primary vessel near the nozzle. A 0.030 -inch $(0.76-\mathrm{mm})$ diameter "Nichrome" igniter wire, shown in Figure 4, was used as an ignition source for the hydrogen-nitrogen jet. The coiled wire was heated to a bright orange color by an electrical current of about 14 amperes. Except for brief instances, the igniter wire was left on when needed for an ignition source. A summary of the test conditions for Test Series $A$ is provided in Table 2.

The results of Test Series A are shown in Table 3 and plotted in Figure 5. The hydrogen ignition percentage is defined as the minimum concentration of hydrogen in the hydrogen-nitrogen mixture flowing through the nozzle that would ignite. As the primary gas temperature was increased from 80 to about $1600^{\circ} \mathrm{F}$, the hydrogen ignition percentage decreased from approximately 12 to 1 percent. After ignition, no residual unburned hydrogen in the secondary vessel was detected. At about $1600^{\circ} \mathrm{F}$, a hydrogen flame was detected with and without the igniter wire, and almost as soon as hydrogen entered the primary vessel. Since earlier runs indicated no hydrogen was left unburned after ignition, the hydrogen was varied only up to 20 or 30 percent and back to zero at this primary gas temperature. 


\section{TABLE 2}

\section{TEST CONDITIONS FOR HYDROGEN FORMATION AND RECOMBINATION TESTS}

\begin{tabular}{|c|c|c|c|c|c|c|c|c|c|c|c|c|c|c|}
\hline \multirow{3}{*}{$\begin{array}{l}\text { Test } \\
\text { Ser es }\end{array}$} & \multirow{3}{*}{$\begin{array}{r}\text { Test } \\
\text { Nurber } \\
\end{array}$} & \multicolumn{4}{|c|}{ Primary Space } & \multicolumn{4}{|c|}{ Secandary Space } & \multirow{3}{*}{$\begin{array}{c}\text { Vent } \\
\text { Prim } \\
\text { ID. In }\end{array}$} & \multirow{3}{*}{$\begin{array}{l}\text { Nozzle } \\
\text { to Sec.) } \\
\text { Materiat }\end{array}$} & \multirow{3}{*}{$\begin{array}{l}\text { Ignition } \\
\text { Source }\end{array}$} & \multirow[b]{3}{*}{ Test Method } & \multirow[b]{3}{*}{ Test arpose } \\
\hline & & $\begin{array}{r}\text { Concen } \\
\quad 17 \\
\end{array}$ & tration & $\begin{array}{l}\text { Wozzle } \\
\text { Flow } \\
\text { Pate, }\end{array}$ & & & $\approx 0_{2}$ & $\begin{array}{l}\text { Tota' } \\
\text { Flow } \\
\text { Rate, }\end{array}$ & & & & & & \\
\hline & & ${ }^{\circ H_{2}}$ & $\mathrm{H}_{2} \mathrm{O}$ & SCFM & Terpp, ${ }^{\circ} \mathrm{F}$ & $\% \mathrm{H}_{2} \mathrm{O}$ & (1) & SCFM & Temp, of & & & & & \\
\hline \multirow{4}{*}{ A } & $\mathrm{HI}$ & $0-100$ & 0 & 0.1 & 65 & (2) & (2) & (2) & (2) & 0.305 & $\$ \$ 304$ & Hot wire & $\begin{array}{l}\text { Vary primary } \\
\mathrm{H}_{2} \text { percent }\end{array}$ & Calibration \\
\hline & $\mu_{2}$ & $0-100$ & 0 & 0.1 & 65 & 0 & 21 & 20 & 100 & 0 305 & 55304 & Hot Wire & $\begin{array}{l}\text { Vary primary } \\
\mathrm{H}_{2} \text { percent }\end{array}$ & $\begin{array}{l}\text { Determine effect of } \\
\text { secondary bessel }\end{array}$ \\
\hline & $\mathrm{H}^{3}$ & $0-100$ & 0 & 0.1 & $400-1600$ & 0 & 21 & 10 & $100-300$ & 0.305 & $5 \$ 304$ & Hot wire & $\begin{array}{l}\text { Vary primary } \\
\text { temperature }\end{array}$ & $\begin{array}{l}\text { Effect of primary } \\
\text { temp on ignition }\end{array}$ \\
\hline & LHA & $0-90$ & 0 & 0.1 & $1600-1400$ & 0 & 21 & 10 & 300 & 0.305 & $S S 304$ & None & $\begin{array}{l}\text { Vary primary } \\
\text { terperature }\end{array}$ & $\begin{aligned} & \text { Effect of primary } \\
& \text { temp. on ignition }\end{aligned}$ \\
\hline E & {$\left[\begin{array}{l}\mathrm{H9} \\
\mathrm{H}, \mathrm{O} \\
\mathrm{H17} \\
\mathrm{H17}\end{array}\right.$} & 75 & 0 & 0.2 & $300-1400$ & 0 & 21 & 2.0 & $100-500$ & 0.430 & $\$ S 304$ & $\begin{array}{l}\text { Sodium } \\
\text { aerosal }\end{array}$ & $\begin{array}{l}\text { Vary primary } \\
\text { temperature } \\
\text { and Na conc }\end{array}$ & $\begin{array}{l}\text { Effect of primary } \\
\text { tenperature and Na } \\
\text { aerosol on ignition }\end{array}$ \\
\hline \multirow[t]{2}{*}{ c } & [HI: & $60-75$ & $0-20$ & $02-0.25$ & 700 & 0 & 21 & 2.0 & 150 & 0430 & 55304 & $\begin{array}{l}\text { Sodium } \\
\text { aerosal }\end{array}$ & $\begin{array}{l}\text { Vary primary } \\
\mathrm{H}_{2} \mathrm{O} \text { conc }\end{array}$ & $\begin{array}{l}\text { Effect of stear } \\
\text { on ignition }\end{array}$ \\
\hline & $\Gamma 416$ & 75 & 0 & 02 & 1425 & 0 & $0-21$ & 2.0 & $450-500$ & 0.430 & SS304 & $\begin{array}{l}\text { Sodium } \\
\text { aerasol }\end{array}$ & $\begin{array}{l}\text { Vary secondary } \\
\mathrm{O}_{2} \text { conc }\end{array}$ & $\begin{array}{l}\text { Effect of secordary } \\
0_{2} \text { conc on burning } \\
\text { efficiency }\end{array}$ \\
\hline \multirow[t]{2}{*}{ D } & H16 & 75 & 0 & 02 & 70 & 0 & $0-2 i$ & 2.0 & $100-260$ & 0.430 & $5 \$ 304$ & Hot Wre & $\begin{array}{l}\text { Vary secondary } \\
\mathrm{O}_{2} \text { cone }\end{array}$ & \multirow{2}{*}{$\begin{array}{l}\text { Effect of secondary } \\
0_{2} \text { conc or burning } \\
\text { efficiency } \\
\text { Effect of secondary } \\
0_{2} \text { conc on } \\
\text { burnirg efficiency }\end{array}$} \\
\hline & LH16 & 75 & 0 & 0.2 & 70 & 0 & $0-21$ & 2.0 & $100-260$ & 0.250 & 55304 & Hot Wre & Vary secondary & \\
\hline$\varepsilon$ & {$[\mathrm{H17}$} & 0 & 0 & 0.7 & 1200 & 0.50 & $0-21$ & $0.2-14$ & 400 & 0430 & $\$ \$ 304$ & $\begin{array}{l}\text { Sodium } \\
\text { aerosol }\end{array}$ & $\begin{array}{l}\text { Vary } \\
\text { secondary } \mathrm{O}_{2} \\
\text { and } \mathrm{H}_{2} \mathrm{O} \text { conc }\end{array}$ & $\begin{array}{l}\mathrm{H}_{2} \text { fonmation in Na- } \\
\text { humd dir } \\
\text { atmosphere }\end{array}$ \\
\hline$F$ & [H18 & 75 & 0 & 2.0 & $300-1400$ & (2) & (2) & (2) & (2) & 0.180 & 55304 & $\begin{array}{l}\text { Sodiun } \\
\text { aerosol }\end{array}$ & $\begin{array}{l}\text { Vary pr'mary } \\
\text { temperature } \\
\text { and ta conc. }\end{array}$ & $\begin{array}{l}\text { Effect of nozzle } \\
\text { velocity on hydrogen } \\
\text { ignition by codiur } \\
\text { aerosol }\end{array}$ \\
\hline
\end{tabular}

(1) At vent nozzle, balance is nitrogen

(2) No secondary vessel, primary vents durectly to outer cell air atmosphere at $80^{\circ} \mathrm{F}$. 
TABLE 3

HYDROGEN IGNITION PERCENTAGE (IP)

AS A FUNCTION OF JET GAS TEMPERATURE

Increasing Hydrogen Percentage

Jet Gas Temperature Ignition ${ }^{\circ} \mathrm{F}\left({ }^{\circ} \mathrm{C}\right)$ Percentage

$\begin{array}{rr}65(18) & 11.0 \\ 65(18) & 12.5 \\ 65(18) & 12.0 \\ 400(204) & 15.0 \\ 400(204) & 11.0 \\ 400(204) & 10.5 \\ 800(427) & 7.5 \\ 820(438) & 8.5 \\ 810(432) & 8.0 \\ 1200(649) & 7.0 \\ 1190(643) & 7.0 \\ 1190(643) & 6.5 \\ 1585(863) & 2.0 \\ 1550(843) & 2.0 \\ 1550(843) & 2.0\end{array}$

Decreasing Hydrogen Percentage Jet Gas Temperature Ignition ${ }^{\circ} \mathrm{F}\left({ }^{\circ} \mathrm{C}\right)$ Percentage

$\begin{array}{rr}65(18) & 11.5 \\ 65(18) & 10.0 \\ 65(18) & 12.0 \\ 430(221) & 10.0 \\ 380(193) & 10.0 \\ 400(209) & 9.0 \\ 760(404) & 7.0 \\ 790(421) & 6.5 \\ 790(421) & 7.5 \\ 1210(654) & 4.0 \\ 1190(643) & 4.5 \\ 1190(643) & 5.5 \\ 1560(848) & 0 \\ 1555(846) & 3.0 \\ 1550(843) & 2.0\end{array}$




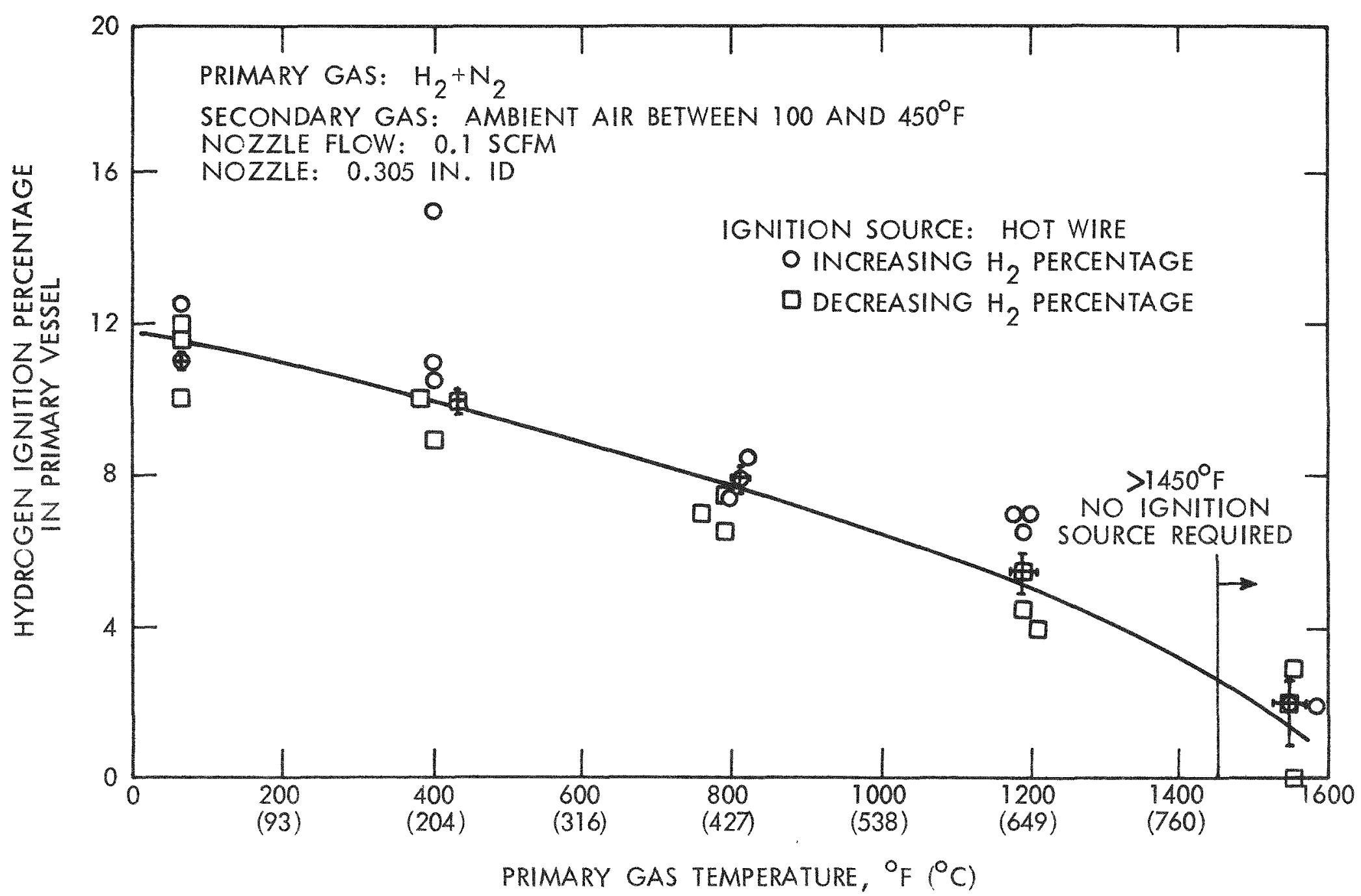

FIGURE 5. Ignition of a Hydrogen-Nitrogen Jet (Without Sodium Aerosol) as a Function of Temperature. 
The ignition percentages 1 isted for about $1550^{\circ} \mathrm{F}$ in Table 3 were derived using the conventional temperature response method discussed in Section 4.1 . For low hydrogen percentages, this method has considerable error, approximately $+1 \%$ hydrogen, and the values listed for this temperature should be taken as an upward limit.

The lower temperature limit where hydrogen will just ignite without an ignition source was determined by flowing a constant low percentage of hydrogen, $4 \%$, through the nozzle at a $0.10-$ SCFM $(2.8-l / \mathrm{min}$ at STP) flowrate and decreasing the primary vessel temperature. Starting at $1550^{\circ} \mathrm{F}\left(843^{\circ} \mathrm{C}\right)$, the primary gas temperature was lowered in $50^{\circ} \mathrm{F}\left(10^{\circ} \mathrm{C}\right)$ increments. At about $1450^{\circ} \mathrm{F}\left(788^{\circ} \mathrm{C}\right)$, the flame began to flicker off and on, and at $1400^{\circ} \mathrm{F}\left(760^{\circ} \mathrm{C}\right)$, the flame went out. The primary vessel was held at $1400^{\circ} \mathrm{F}\left(760^{\circ} \mathrm{C}\right)$ and the hydrogen varied up to 20 percent and about 1 SCFM $(28.3 \mathrm{l} / \mathrm{min}$ at STP). The hydrogen did not re-ignite. A time scenario of the hydrogen flame characteristics and primary gas temperature is shown in Figure 6 . The flame edge temperatures were recorded by the thermocouple arrangement shown in Figure 4. The burning efficiency of the hydrogen flame decreased rapidly as the primary gas temperature was reduced from $1450^{\circ} \mathrm{F}\left(788^{\circ} \mathrm{C}\right)$ to $1400^{\circ} \mathrm{F}\left(760^{\circ} \mathrm{C}\right)$ and the flame began to flicker.

\subsection{Test Series B - Ignition of Hydrogen-Nitrogen-Sodium Jets}

The objective of Test Series $B$ was to determine if sodium vapor and/or aerosol is a reliable ignition source for hydrogen jets and, if so, under what conditions.

The tests were conducted by flowing a hydrogen-nitrogen-sodium gas mixture through the primary vessel, through the nozzle, and into the air atmosphere of the secondary vessel. The primary gas mixture contained 70 to 80 percent hydrogen with various amounts of sodium vapor/aerosol. The concentration of sodium in the primary vessel was controlled by heating containers of sodium either inside or connected to the primary vessel to various temperatures. The ignition characteristics of the jet were observed for various primary gas temperatures. Included in these observed ignition characteristics were whether or not the jet ignited with various sodium vapor/aerosol concentrations, flame shape, ignition source, residual hydrogen unburned, and time between flame extinguishment and re-ignition. As in all of the test series, the primary gas 


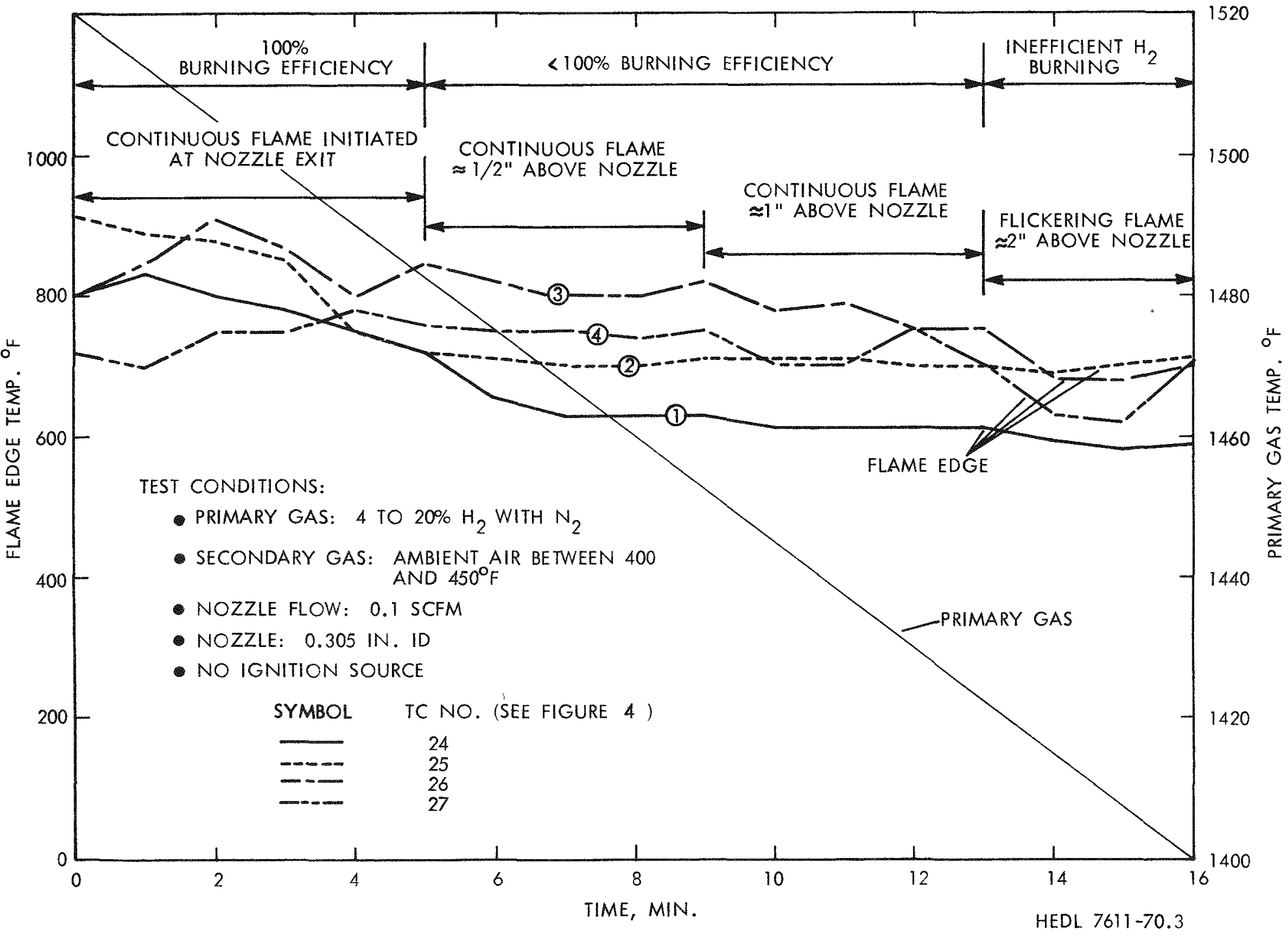

FIGURE 6. Time History Illustrating Hydrogen Jet Burning Characteristics and Origin of $1450^{\circ} \mathrm{F}$ Auto-Ignition Temperature Limit. 
temperatures were measured by thermocouples located in the atmosphere with in the primary vessel near the inlet of the nozzle. The temperature indicated by these thermocouples is expected to be very nearly the same as that of the gas at the outlet of the nozzle. The test conditions for Test Series B are summarized in Table 2. An accumulation of 8 percent hydrogen in the secondary vessel was allowed, which never resulted in an explosion upon ignition.

Higher hydrogen concentrations in a few instances resulted in minor explosions that did no damage.

Several tests conducted throughout the test program produced the data shown in Figure 7. Each data point represents an observation of the hydrogen jet ignition characteristics for a particular primary (or jet) gas temperature and a particular primary sodium vapor/aerosol concentration. The observations are in terms of "immediate ignition," "no immediate ignition," and "no ignition." "Immediate ignition" refers to cases where the jet would re-ignite within a few seconds after intentional flame extinguishment. The flame was extinguished by stopping briefly the gas flow through the nozzle. "No immediate ignition" refers to those instances when re-ignition did not occur reliably for at least a few minutes after flame extinguishment. "No ignition" refers to those cases where reliable ignition did not occur at a11. Random ignition occurrences were frequent throughout the tests, and once the jet ignited it remained burning until it was extinguished intentionally.

During the tests, three forms of sodium were entrained in the jet gas stream. For the purpose of discussing the results and observations, these sodium forms are defined as: sodium vapor, sodium aerosol particles formed by vapor condensation and agglomeration, and droplets which are large sodium particles formed by deposition or condensation on the nozzle surfaces and re-entrained by the jet gas. The ordinate in Figure 7 includes sodium in the first two forms but not the droplets. As discussed earlier, the sodium concentration in the primary vessel was controlled by heating a container of sodium. If the sodium temperature was higher than the primary vessel walls, the primary gas contained a saturated amount of sodium vapor and some amount of condensation in the form of aerosols. A small, faint flame, assumed to be sodium vapor illuminescence, was present above the nozzle at primary gas temperatures above $500^{\circ} \mathrm{F}\left(260^{\circ} \mathrm{C}\right)$. The "flame" was about $1 / 2$-inch $(13 \mathrm{~mm})$ 


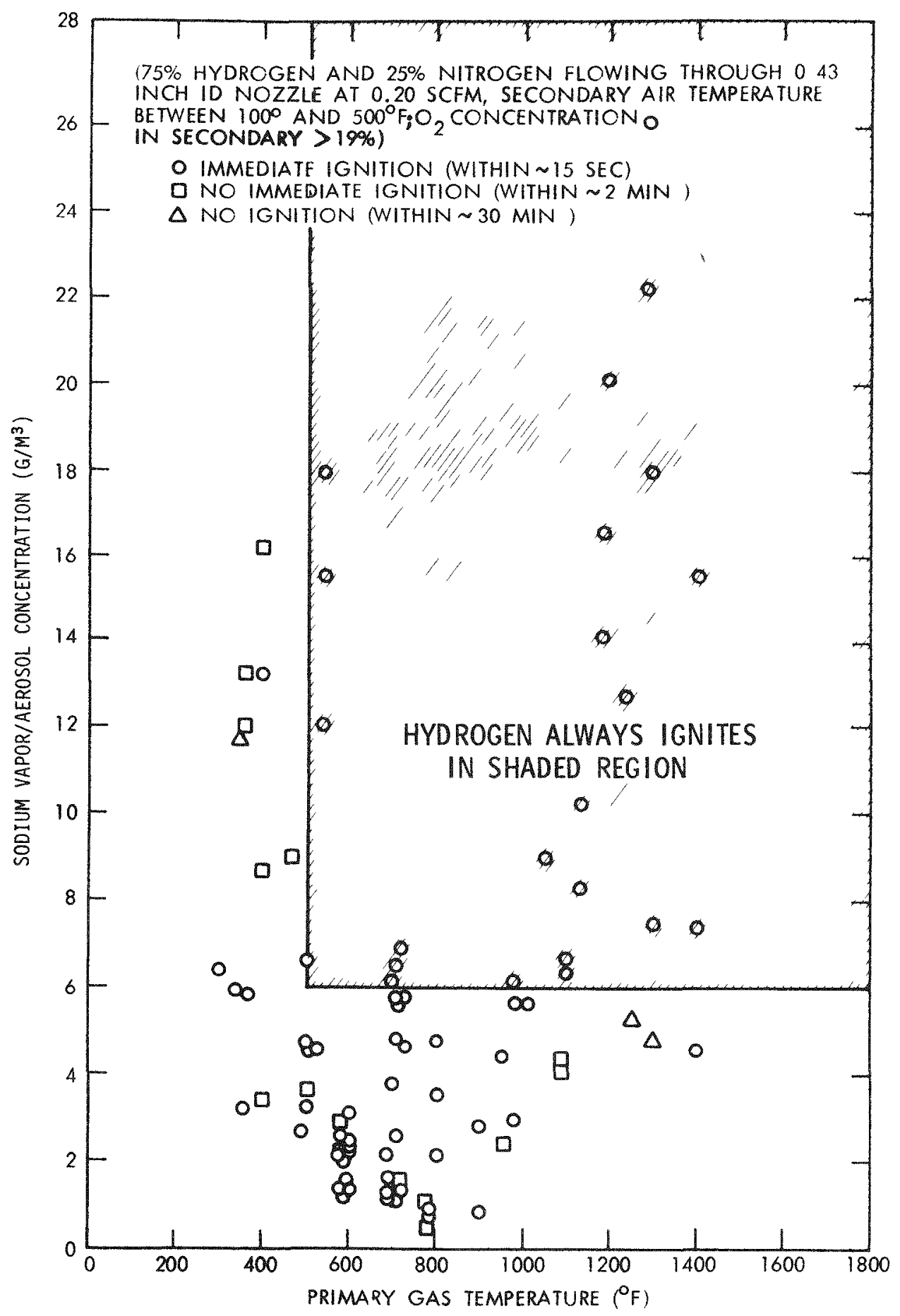

FIGURE 7. Conservative Limits for Hydrogen-Sodium Jet Ignition. 
high at the low gas temperatures and increased up to approximately 3 inches $(76 \mathrm{~mm}$ ) high with increased sodium concentration and gas temperature. The size and brightness of the vapor flame correlated with the probable amount of sodium vapor. Cascade impactor sampling of the primary vessel atmosphere indicated that the mass median aerodynamic diameter of the aerosol particles was $1.5 \mu \mathrm{m}$, with the standard geometric deviation of 3.7. Nozzle plugging and sodium droplets released in the jet occurred as a direct function of the probable amount of sodium aerosol present in the primary vesse1. From visual observations, the size of the droplets formed was estimated to be 100 to $1000 \mu \mathrm{m}$ diameter. No nozzle plugging and very few droplets were observed when only sodium vapor was present in the primary vessel (sodium temperature equal or less than primary gas temperature).

Figure 8 presents the same data as shown in Figure 7, with the addition of two curves. Curve " $A$ " is the saturated vapor concentration, calculated by using the perfect gas law and using the vapor pressure of sodium at the indicated primary gas temperature. Curve " $B$ " is the authors' hand-drawn line dividing the region where immediate ignition was always observed (region above the curve) from the region below the curve where ignition was unreliable. At low gas temperatures, ignition occurred with various sodium concentrations but with no definite pattern until the gas temperature reached approximately $500^{\circ} \mathrm{F}\left(260^{\circ} \mathrm{C}\right)$. It was noticed during the tests that the sodium droplets did not burn upon entering the air until the jet gas temperature was at least $300^{\circ} \mathrm{F}\left(150^{\circ} \mathrm{C}\right)$. The number of droplets that burned increased with increasing gas temperature until at $500^{\circ} \mathrm{F}$ $\left(260^{\circ} \mathrm{C}\right)$ almost a 11 ignited.

The data of Figure 8 suggest that between 500 and $800^{\circ} \mathrm{F}\left(260\right.$ to $\left.427^{\circ} \mathrm{C}\right)$ the sodium concentration needed for ignition decreased-probably due to the fact that hydrogen needs less added energy for ignition as its temperature increases. In this temperature range, the sodium vapor concentration was insignificant and the sodium was predominately aerosol particles. As the sodium concentration decreased, hotter, fewer, and perhaps smaller sodium particles were capable of providing necessary added energy for ignition of the hydrogen jet.

At about $700^{\circ} \mathrm{F}\left(370^{\circ} \mathrm{C}\right)$, the saturated sodium vapor concentration becomes significant for hydrogen ignition purposes. As the sodium vapor in the primary gas begins to increase, less vapor condensation occurs and fewer sodium aerosol 


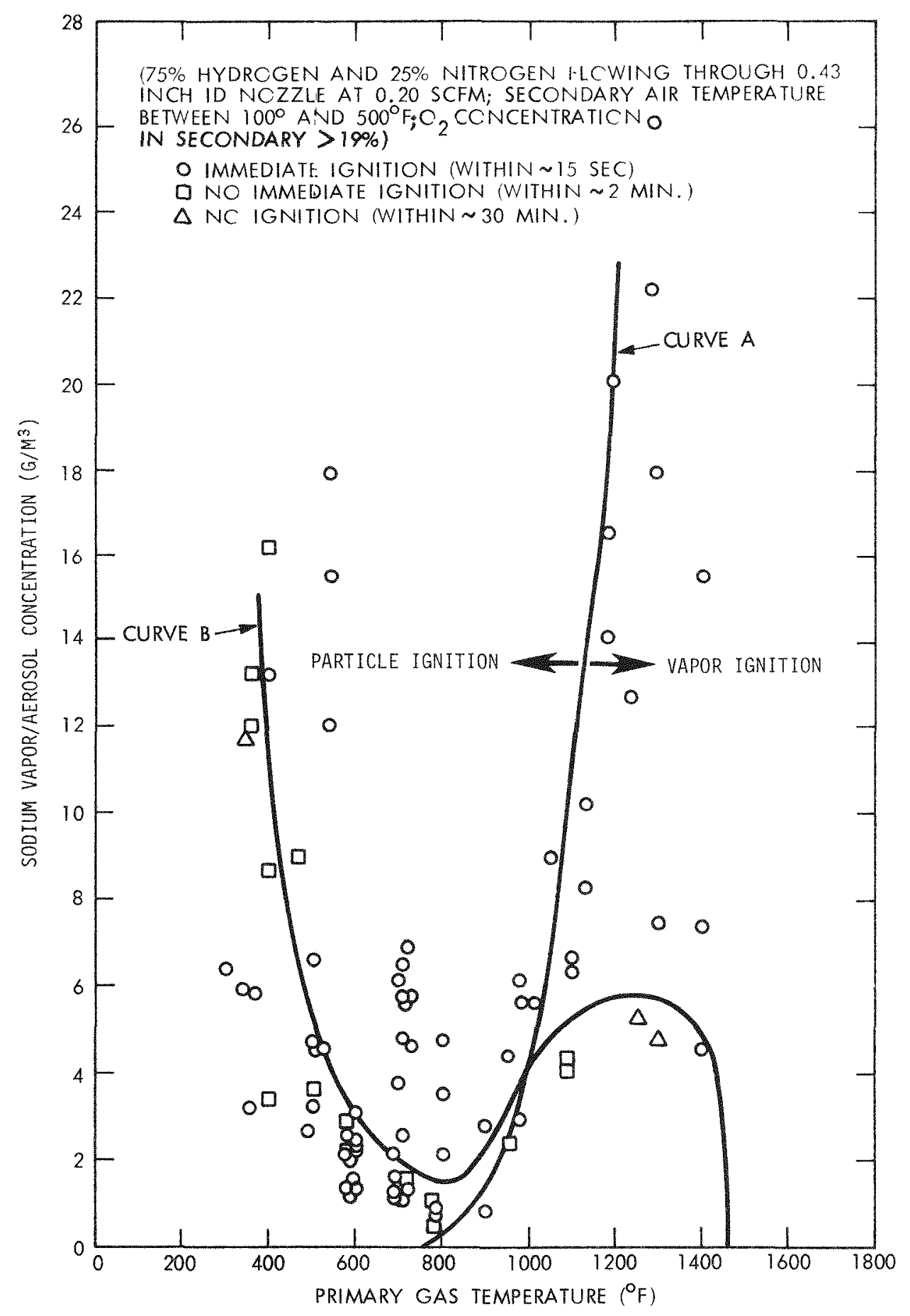

FIGURE 8. Ignition Characteristics of a Hydrogen-Sodium Jet. 
particles and droplets are formed. Apparently, as shown by the data of Figure 8 , the saturation sodium vapor concentration between the gas temperatures of 700 and $1000^{\circ} \mathrm{F}\left(370\right.$ to $\left.538^{\circ} \mathrm{C}\right)$ is not sufficient to produce enough heat per volume of hydrogen to cause ignition. The main source of ignition is still the sodium aerosol particles and droplets; therefore, the sodium concentration had to increase between those gas temperatures for sodium vapor condensation and droplet formation to occur.

At about $1000^{\circ} \mathrm{F}\left(538^{\circ} \mathrm{C}\right)$, the primary gas contained enough sodium vapor for ignition and sodium particles were no longer required. During the tests, the quantity of sodium particles and droplets released from the nozzle decreased to almost zero at this temperature while the vapor flame continued to increase in size. Curve B slopes downward from approximately $1200^{\circ} \mathrm{F}\left(650^{\circ} \mathrm{C}\right)$ because, as mentioned before, hydrogen requires less added energy for ignition with increased temperature. The curve is sloped to 0 at $1450^{\circ} \mathrm{F}\left(790^{\circ} \mathrm{C}\right)$ because the results from Test Series $A$ indicated hydrogen auto-ignites at this temperature with no external ignition source. To determine if hydrogen ignition is affected by the presence of too much sodium, tests were conducted using sodium concentrations far exceeding the critical amount needed for ignition. By keeping the primary gas the same temperature as the sodium generator, a saturated sodium curve was generated at the same time. No difference in ignition was noticed for sodium vapor concentrations as high as $22 \mathrm{~g} / \mathrm{m}^{3}$.

In summary, the data from Test Series $B$ indicate that there are two forms of sodium responsible for the ignition of a hydrogen jet-particle and vapor. Particle forms include sodium aerosols, formed from sodium vapor condensation and agglomeration, and droplets of sodium formed by plate-out and re-entrainment in the leak path. Unlike sodium vapor, the particles produce "sparks" that act like minute ignition points. Due to the unpredictable occurrence of the re-entrained particles, the ignition of a hydrogen jet cannot be a well-defined process. However, the limits shown in Figure 7 are believed to define conservatively the minimum values of sodium concentration and jet gas temperature required for ignition.

\subsection{Test Series C - Ignition of Hydrogen-Nitrogen-Sodium-Water Jets}

The objective of Test Series $C$ was to determine if water vapor added to the primary flows of hydrogen, nitrogen, and sodium vapor/aerosol would 
affect the ignition characteristics of the jet.

As shown in Table 2, the primary gas temperature was held at $700^{\circ} \mathrm{F}$ $\left(371^{\circ} \mathrm{C}\right)$, the secondary gas was between 120 and $200^{\circ} \mathrm{F}\left(50\right.$ to $93^{\circ} \mathrm{C}$ ), the flow rate through the $0.43-$ inch $(10.9-\mathrm{mm})$ ID nozzle was 0.2 SCFM $(5.7 \mathrm{l} / \mathrm{min}$ at STP) of approximately 80 percent hydrogen/20 percent nitrogen, the sodium vapor and aerosol concentration was held fairly constant at 1.2 to $6 \mathrm{~g} / \mathrm{m}^{3}$, and the steam flow to the primary vessel was varied.

The test procedure steps were: (1) set the primary vessel temperature at $700^{\circ} \mathrm{F}\left(371^{\circ} \mathrm{C}\right),(2)$ establish a flow of dry hydrogen-nitrogen mixture to the primary vesse1, and (3) increase the sodium vapor/aerosol concentration unti1 the critical amount needed for hydrogen ignition was reached. Water vapor was then added to the primary gas flow at rates varying from 0.0014 to 0.059 SCFM (0.04 to $1.7 \mathrm{\ell} / \mathrm{min}$ at STP).

Throughout the testing, no effect of the added steam on the hydrogen ignition was observed. The primary hydrogen concentration increased siightly (about 3 percent) while adding the higher steam flows, indicating sodium-water reactions. Immediate ignition of the hydrogen jet always re-occurred after flame extinguishment even when the amount of steam injected was 35 times the amount needed to react all of the sodium vapor/aerosol present in the primary vessel.

\subsection{Test Series D - Effects of Oxygen Depletion on Hydrogen Burning}

The objective of Test Series $D$ was to determine the burning efficiency of a hydrogen-nitrogen jet as a function of the oxygen concentration supplied to the flame region.

Three tests were conducted using the test conditions summarized in Table 2. The first test used $1425^{\circ} \mathrm{F}\left(774^{\circ} \mathrm{C}\right)$ primary gas temperature, 450 to $500^{\circ} \mathrm{F}(232$ to $260^{\circ} \mathrm{C}$ ) secondary gas temperature, 75 percent hydrogen $/ 25$ percent nitrogen flowing at 0.2 SCFM $(5.7 \mathrm{l} / \mathrm{min}$ at STP) through a $0.43-$ inch $(10.9-\mathrm{mm})$ ID nozzle along with approximately $7.4 \mathrm{~g} / \mathrm{m}^{3}$ of sodium. Variable amounts of oxygen and nitrogen at 2.0 SCFM (57 l/min at STP) were supplied to the secondary vessel. During the second test, the same gas flows were used, the primary and secondary vessels were at room temperature, and no sodium vapor/aerosol was present in the jet stream. An artificial ignition source, e.g., an igniter wire, was 
used periodically to ignite the hydrogen jet. The third test was the same as the second test, except that a smaller, 0.25-inch ID, nozzle was used for producing a higher jet velocity.

The same test procedure was used for all three tests. After the test conditions were established and the hydrogen jet ignited, the oxygen concentration supplied to the secondary vessel was decreased while monitoring the hydragen concentration in the exhaust gases leaving the secondary vessel.

The burning efficiency, $E_{B}$, was calculated by Equation (1):

$$
E_{B}=1-\frac{C_{2} F_{2}}{C_{1} F_{1}}
$$

where $\quad C_{7}=$ hydrogen concentration in jet, mole fraction

$C_{2}=$ hydrogen concentration in secondary vessel exhaust, mole fraction

$F_{1}=$ jet flowrate, $\mathrm{m}^{3} / \mathrm{min}$

$F_{2}=$ secondary vessel exhaust flowrate, $\mathrm{m}^{3} / \mathrm{min}$

The results of each test are plotted in Figures 9, 10, and 11 . During the first test, the hydrogen burned at 100 percent efficiency until the supplied oxygen concentration was 15.5 percent. At this point, the flame began to shrink in size and the burning efficiency decreased until at 10 percent oxygen only infrequent wisps of flame occurred. Below 10 percent supplied oxygen, no flames were observed and hydrogen recombination did not occur.

The supplied oxygen concentrations were measured by sampling and analyzing the gas supplied to the secondary vessel. The oxygen concentration in the exhaust gas from the secondary vessel was also recorded and is plotted in Figure 12. The extent of gas mixing in the secondary vessel was not determined, but is believed to be significant. The actual oxygen concentration of the gas feeding into the flame was probably between the supplied and exhaust gas oxygen concentration curves, shown in Figure 12.

The results of the second and third tests, using room-temperature gases and no sodium, indicated a sharper cut-off of the burning efficiency at about 


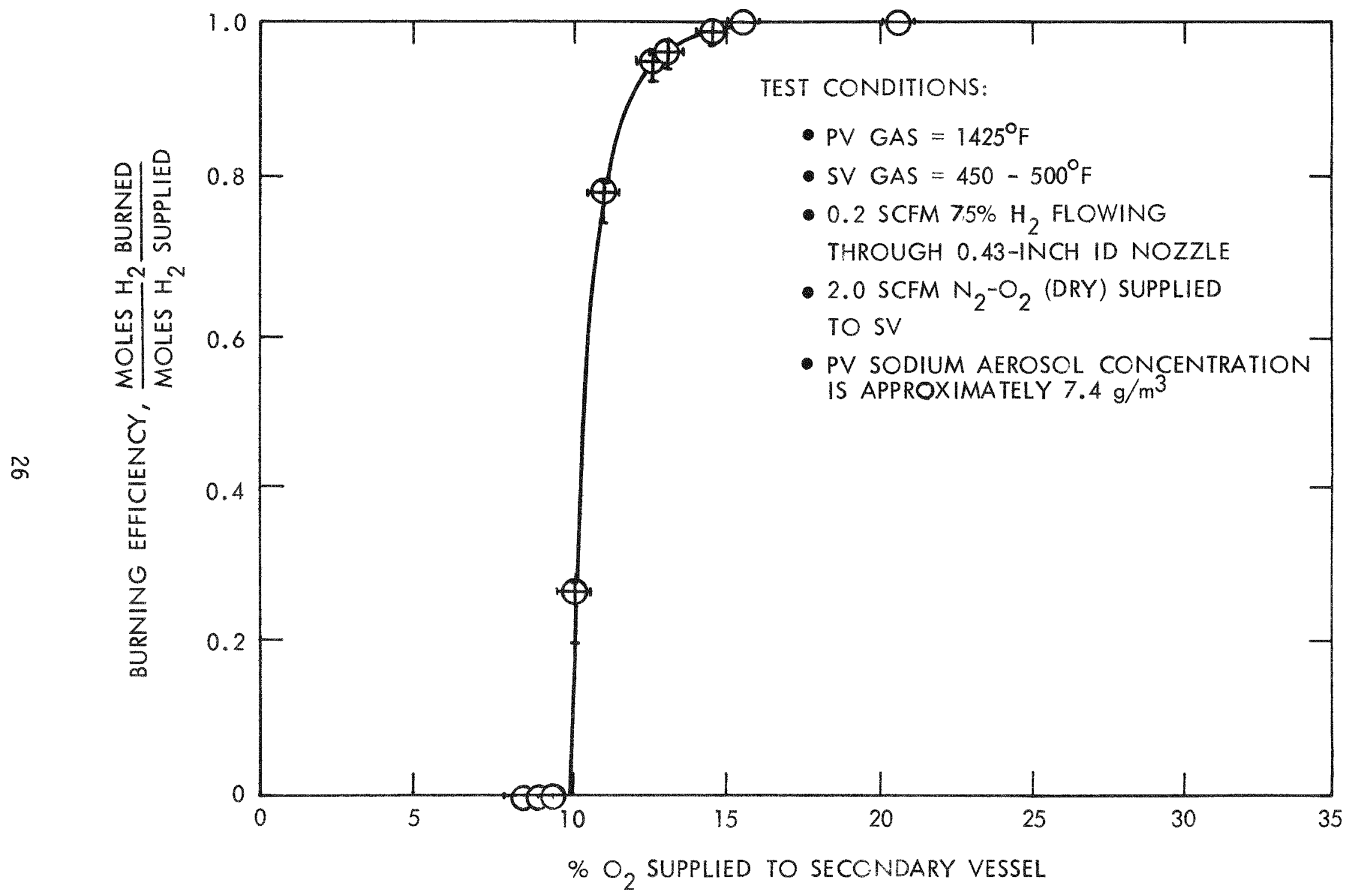

FIGURE 9. Effect of 0xygen Depletion on Hydrogen Burning Efficiency of a Hydrogen-Nitrogen-Sodium Jet. 


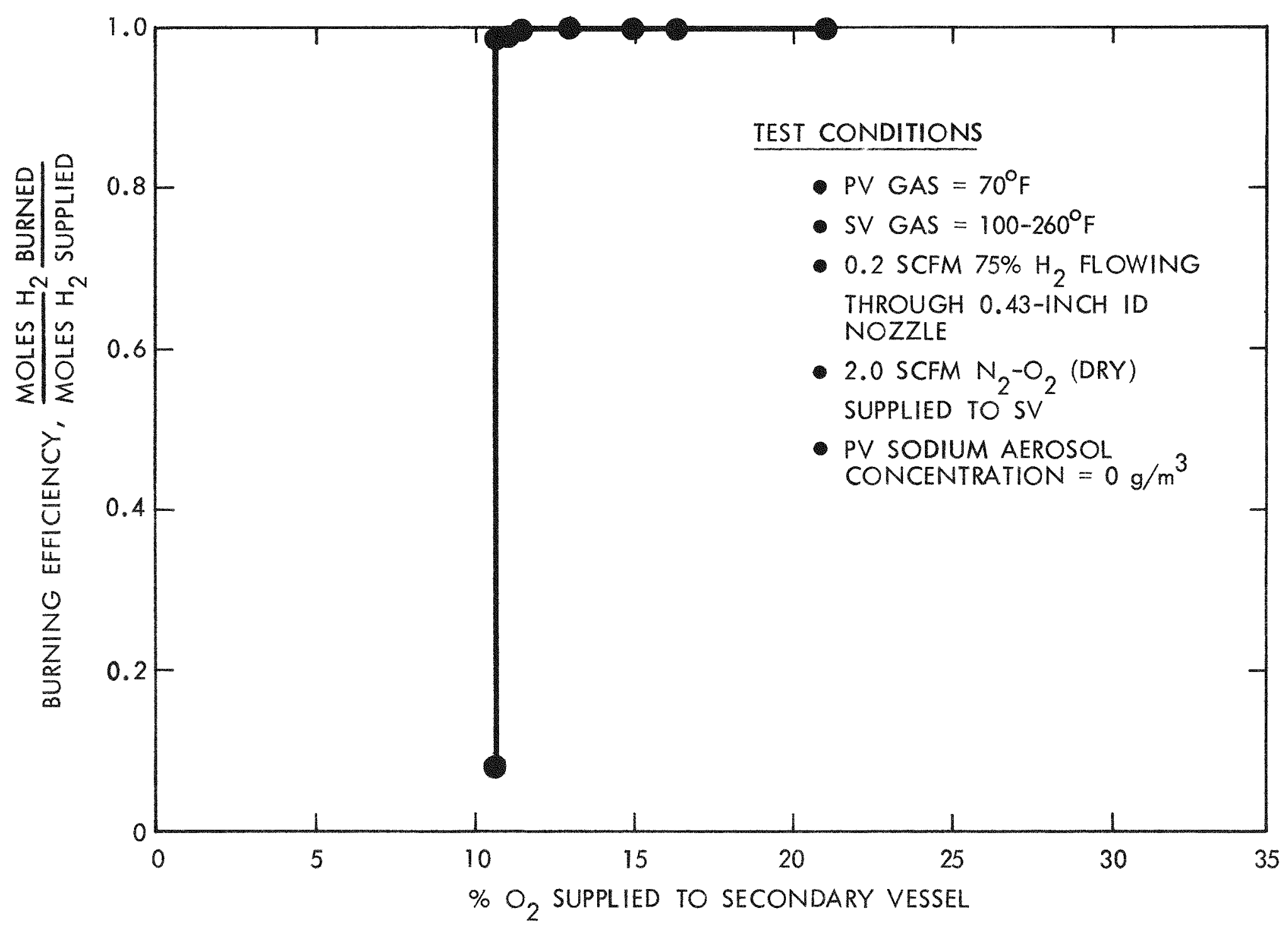

FIGURE 10. Effect of Oxygen Depletion on Hydrogen Burning Efficiency of a Hydrogen-Nitrogen Jet (Without Sodium Aerosol). 


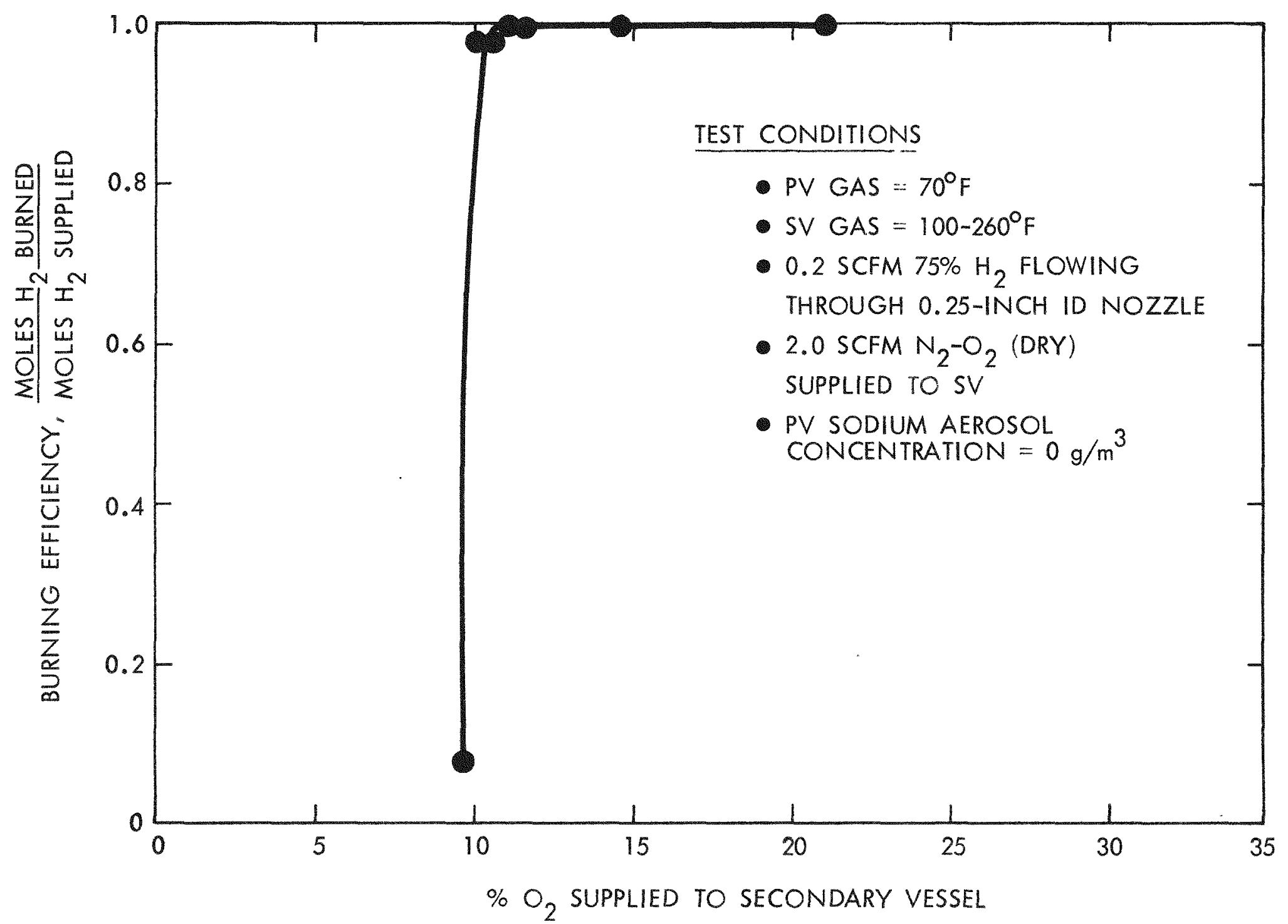

FIGURE 11. Effect of Oxygen Depletion on Hydrogen Burning Efficiency of a Hydrogen-Nitrogen Jet at a Higher Velocity. 


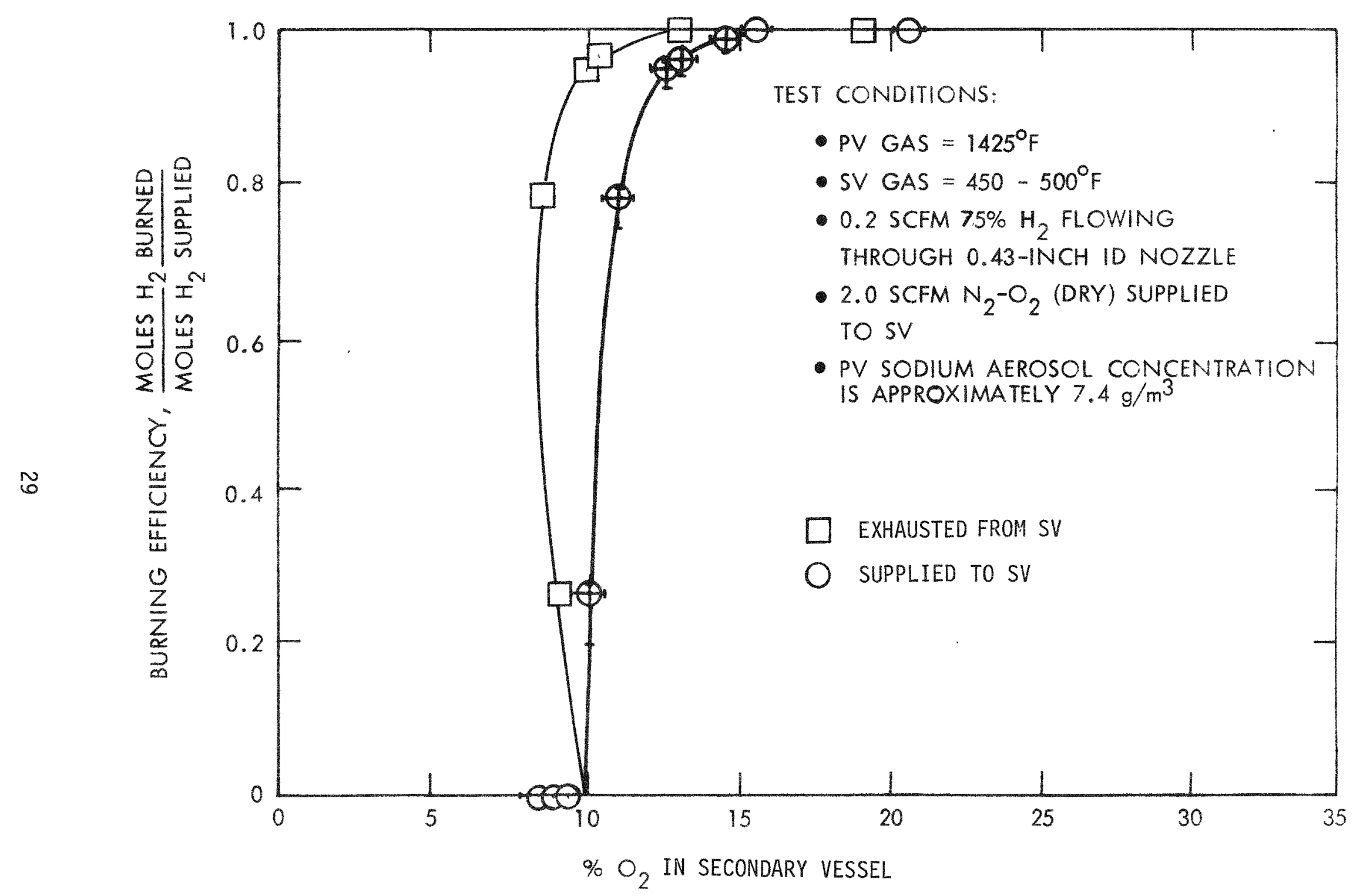

FIGURE 12. Hyárogen Burning Efficiency of a Hydrogen-Nitrogen-Sodium Jet as a Function of the Supplied and Exhausted Oxygen Concentrations. 
10 percent oxygen. The hydrogen jet in these tests either burned or didn't burn, probably due to the absence of a continuous ignition source such as the sodium. In both tests, the hydrogen jet ceased to burn when the oxygen concentration in the supplied gas decreased below 10 percent.

\subsection{Test Series E - Hydrogen Formation in Sodium-Water-Air Atmospheres}

A study of hydrogen formation in sodium-humid air atmospheres was the objective of Test Series E. During a melt-through accident in which the reactor cavity 1 iners do not fail, steam and sodium vapor/aerosol would probably be released via separate vent lines to the RCB atmosphere where they could interact to form hydrogen. This test series was designed to determine the quantity of hydrogen formed as a function of the ratio of oxygen to water vapor concentration.

The test procedure was to: (1) heat the primary vessel to $1200^{\circ} \mathrm{F}\left(649^{\circ} \mathrm{C}\right)$ which, in turn, heated the secondary vessel to about $400^{\circ} \mathrm{F}\left(204^{\circ} \mathrm{C}\right)$, (2) adjust the primary sodium vapor/aerosol concentration to about $20 \mathrm{~g} / \mathrm{m}^{3}$, (3) set the nitrogen flow through the 0.43 -inch ID nozzle at 0.75 SCFM (21 $\mathrm{\ell} / \mathrm{min}$ at STP), and then (4) vary the secondary oxygen and water vapor concentrations and flowrates. A list of the test conditions and test cases is shown in chronological order in Table 4. The data are plotted in Figure 13. For each case, the data were taken when equilibrium conditions were established and the amount of oxygen and/or water vapor was in excess of that required to completely react all the sodium. No hydrogen was detected in the secondary vessel exhaust flow when the molar ratio, $\mathrm{O}_{2} /\left(\mathrm{H}_{2} \mathrm{O}+\mathrm{O}_{2}\right)$, in the secondary vessel supply gas stream was greater than 0.5 . Due to problems with the oxygen analyzers, the oxygen concentrations in the gas supplied to the secondary vessel were calculated from the gas flows measured by rotameters. The oxygen concentrations in the outlet gas stream are provided in Table 4 for comparison but should not be used in data calculations. The water vapor content was calculated assuming saturation by the humidifier and referring to standard saturated water vapor tables. A schematic drawing of the humidifier is shown in Appendix $A$ as Figure A-5. The hydrogen concentration was measured in the exhaust gas by three hydrogen analyzers connected in series, giving an accuracy of \pm 0.02 percent hydrogen. 


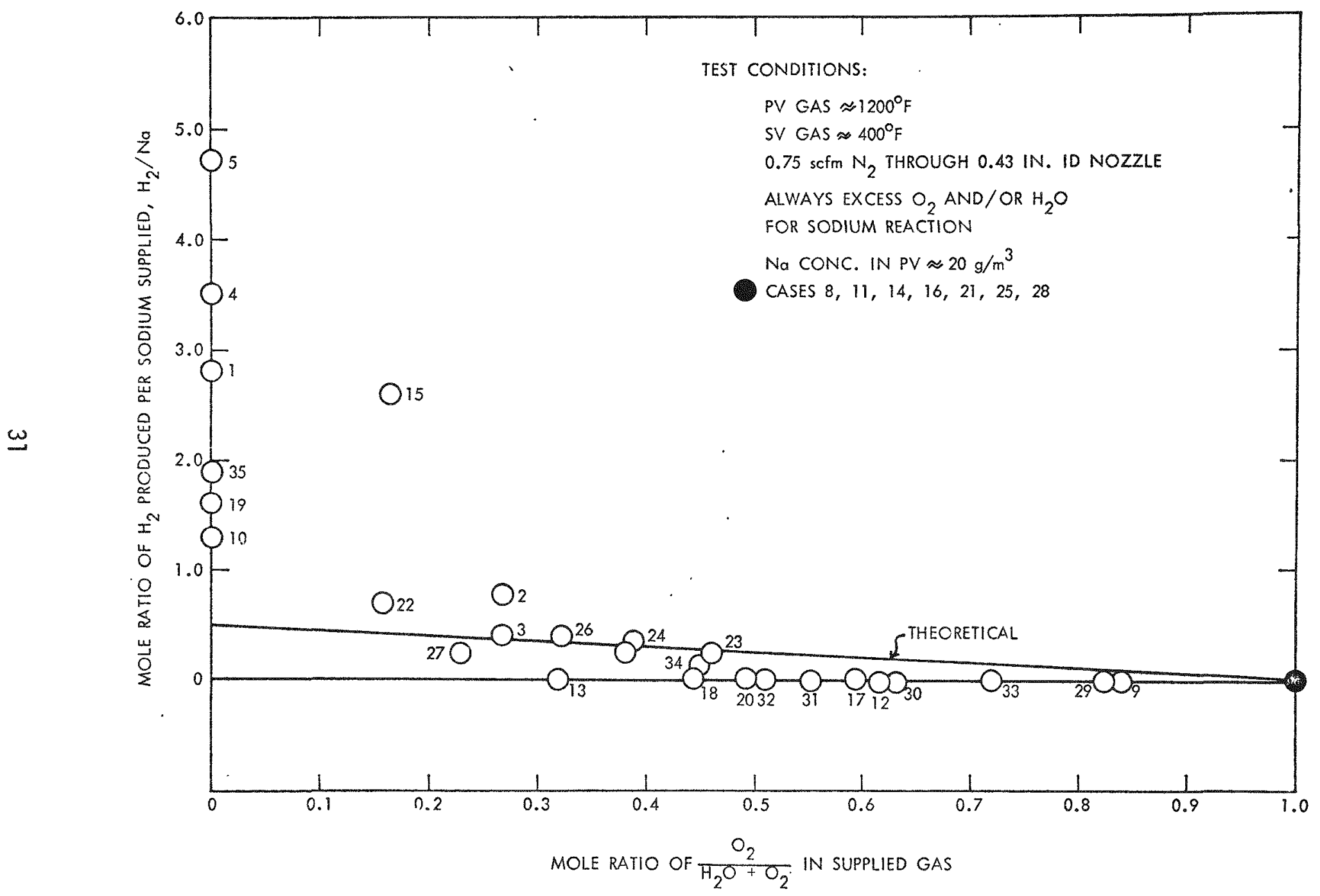

FIGURE 13. Hydrogen Formation in Sodium-Humid Nitrogen-Oxygen Atmospheres. 
TABLE 4

TEST MEASUREMENTS FOR TEST SERIES E

\begin{tabular}{|c|c|c|}
\hline \multirow[b]{2}{*}{ Case } & \multicolumn{2}{|c|}{$\begin{array}{c}\text { Primary Vessel } \\
\text { Flow Rate, } \\
\text { G Moles/Minute }\end{array}$} \\
\hline & Nitrogen & Sodium \\
\hline $\begin{array}{l}1 \\
2 \\
3 \\
4 \\
5\end{array}$ & $\begin{array}{l}0.9475 \\
0.9475 \\
0.9475 \\
0.9475 \\
0.9475\end{array}$ & $\begin{array}{l}0.01495 \\
0.01393 \\
0.01640 \\
0.01444 \\
0.01412\end{array}$ \\
\hline $\begin{array}{r}6 \\
8 \\
9 \\
10\end{array}$ & $\begin{array}{l}0.9475 \\
0.9475 \\
0.9475 \\
0.9475\end{array}$ & $\begin{array}{l}0.01533 \\
0.01565 \\
0.01793 \\
0.01745\end{array}$ \\
\hline $\begin{array}{l}11 \\
12 \\
13 \\
14 \\
15\end{array}$ & $\begin{array}{l}0.9475 \\
0.9475 \\
0.9475 \\
0.9475 \\
0.9475\end{array}$ & $\begin{array}{l}0.01956 \\
0.01859 \\
0.01761 \\
0.01550 \\
0.02022\end{array}$ \\
\hline $\begin{array}{l}16 \\
17 \\
18 \\
19 \\
20\end{array}$ & $\begin{array}{l}0.9475 \\
0.9475 \\
0.9475 \\
0.9475 \\
0.9475\end{array}$ & $\begin{array}{l}0.01343 \\
0.01689 \\
0.01715 \\
0.01435 \\
0.01455\end{array}$ \\
\hline $\begin{array}{l}21 \\
22 \\
23 \\
24 \\
25 \\
26 \\
27 \\
28 \\
29 \\
30\end{array}$ & $\begin{array}{l}0.9475 \\
0.9475 \\
0.9475 \\
0.9475 \\
0.9475 \\
0.9475 \\
0.9475 \\
0.9475 \\
0.9475 \\
0.9475\end{array}$ & $\begin{array}{l}0.01370 \\
0.01350 \\
0.01180 \\
0.01076 \\
0.00942 \\
0.00854 \\
0.00874 \\
0.02107 \\
0.01735 \\
0.01859\end{array}$ \\
\hline $\begin{array}{l}31 \\
32 \\
33 \\
34 \\
35\end{array}$ & $\begin{array}{l}0.9475 \\
0.9475 \\
0.9475 \\
0.9475 \\
0.9475\end{array}$ & $\begin{array}{l}0.01891 \\
0.01696 \\
0.01794 \\
0.01565 \\
0.01598\end{array}$ \\
\hline
\end{tabular}

\begin{tabular}{|c|c|c|}
\hline \multicolumn{3}{|c|}{$\begin{array}{l}\text { Secondary Vessel Inlet } \\
\text { Flow Rate, G Moles/Minute }\end{array}$} \\
\hline oxygen & Nitrogen & Water Vap \\
\hline $\begin{array}{c}0 \\
0.0531 \\
0.1061 \\
0 \\
0\end{array}$ & $\begin{array}{l}0.2527 \\
0.1996 \\
0.3992 \\
0.5054 \\
0.9475\end{array}$ & $\begin{array}{l}0.08352 \\
0.14578 \\
0.29156 \\
0.23505 \\
0.37055\end{array}$ \\
\hline $\begin{array}{c}0.1990 \\
0.1990 \\
0.1990 \\
0\end{array}$ & $\begin{array}{l}0.7486 \\
0.7486 \\
0.7486 \\
0.9475\end{array}$ & $\begin{array}{c}0.32440 \\
0 \\
0.03772 \\
0.03297\end{array}$ \\
\hline $\begin{array}{l}0.2653 \\
0.2653 \\
0.1990 \\
0.0531 \\
0.0531\end{array}$ & $\begin{array}{l}0.9981 \\
0.9981 \\
0.7486 \\
0.1996 \\
0.1996\end{array}$ & $\begin{array}{c}0 \\
0.16587 \\
0.42562 \\
0 \\
0.26779\end{array}$ \\
\hline $\begin{array}{c}0.0531 \\
0.0531 \\
0.0531 \\
0 \\
0.0663\end{array}$ & $\begin{array}{l}0.1996 \\
0.1996 \\
0.4523 \\
0.6317 \\
0.8812\end{array}$ & $\begin{array}{c}0 \\
0.03646 \\
0.06635 \\
0.04982 \\
0.06366\end{array}$ \\
\hline $\begin{array}{l}0.0663 \\
0.0663 \\
0.1990 \\
0.1990 \\
0.1990 \\
0.1990 \\
0.0663 \\
0.0663 \\
0.0663 \\
0.0663\end{array}$ & $\begin{array}{l}0.8812 \\
1.1971 \\
0.7486 \\
1.0644 \\
1.0644 \\
1.0644 \\
1.1971 \\
0.2495 \\
0.2495 \\
0.8812\end{array}$ & $\begin{array}{c}0 \\
0.35434 \\
0.23418 \\
0.31224 \\
0 \\
0.40485 \\
0.21933 \\
0 \\
0.01390 \\
0.04025\end{array}$ \\
\hline $\begin{array}{c}0.0663 \\
0.0663 \\
0.1990 \\
0.1990 \\
0\end{array}$ & $\begin{array}{l}1.1971 \\
1.5129 \\
0.7486 \\
1.3803 \\
0.9475\end{array}$ & $\begin{array}{l}0.05367 \\
0.06709 \\
0.07740 \\
0.24265 \\
0.08761\end{array}$ \\
\hline
\end{tabular}

\begin{tabular}{l} 
Secondary Vessel Outlet \\
Flow Rate, G Moles/Minute \\
\hline Oxygen Hydrogen
\end{tabular}

0
0.0120
0.0705
0
0

0.1725

0.1988

0.1937

0

0.2501

0.2593

0.2562

0.0295

0.0384

0.03700

0.03667

0.04707

0.01203

0.06728

0.06254

0.07517

0.21983

0.23878

0.24320

0.24099

0.16140

0.05559

0.04194

0.05496

0.05616

0.05812

0.1990

0.2034

0.04201
0.01080
0.00554
0.05085
0.06633

0.06633

0.00379

0.00038

0.02274

0
0

0

0

0.05281

0

0.00073

0.02274

0.00038

0

0.00973

0.00284

0.00387

0

0.00354

0.00221

0
0

0

0

000379

0.001263

0.028805
Mole Ratio $\overline{\mathrm{Na}} \overline{\mathrm{H}} \mathrm{O}+\mathrm{O}_{2}$.

$\begin{array}{cc}2.810 & 0 \\ 0.775 & 0.267 \\ 0.399 & 0.267 \\ 3.521 & 0 \\ 4.698 & 0\end{array}$

$0.247 \quad 0.380$

$\begin{array}{cc}0 & 1.0 \\ 0.021 & 0.841\end{array}$

$\begin{array}{ll}0.021 & 0.841 \\ 1.303 & 0\end{array}$

$0 \quad 1.0$

$\begin{array}{ll}0 & 0.615\end{array}$

$0 \quad 0.319$

$\begin{array}{ll}0 & 1.0\end{array}$

$2.672 \quad 0.165$

$0 \quad 1.0$

$0.043 \quad 0.445$

$1.585 \quad 0$

$0.026 \quad 0.490$

$\begin{array}{cc}0 & 1.0 \\ 0.721 & 0.158\end{array}$

$0.727-0.158$

$\begin{array}{ll}0.721 & 0.158 \\ 0.360 & 0.389\end{array}$

$0 \quad 1.0$

$0.414 \quad 0.323$

$\begin{array}{lll}0.253 & 0.232\end{array}$

$\begin{array}{ll}0 & 1.0 \\ 0 & 0.827\end{array}$

$0 \quad 0.622$

$\begin{array}{ll}0 & 0.553\end{array}$

$\begin{array}{cc}0 & 0.497 \\ 0.621 & 0.720\end{array}$

$\begin{array}{ll}0.621 & 0.720 \\ 0.803 & 0.451\end{array}$

$\begin{array}{ll}1.803 & 0\end{array}$ 
The theoretical curve shown in Figure 13 was calculated assuming the sodium reacts with the water vapor and oxygen according to their molar concentrations and forms $\mathrm{Na}_{2} \mathrm{O}$. If all of the reactions were complete for each case, the ratio $\mathrm{H}_{2} / \mathrm{Na}$ could not be greater than 0.5 . As shown by the data in Figure 13, however, the ratio $\mathrm{H}_{2} / \mathrm{Na}$ greatly exceeded 0.5 at low oxygen/high water vapor concentrations. One plausible explanation for the apparent excess of hydrogen is based on the observation that an accumulation of metallic sodium occurred on the floor of the secondary vessel during tests with high oxygen-to-water ratios. It is postulated that the metallic sodium was protected from low concentrations of water vapor by a thin sodium oxide layer. As the moisture content around the particles was raised, the solid oxide layer turned to a liquid sodium hydroxide layer. The ratio $\mathrm{O}_{2} /\left(\mathrm{H}_{2} \mathrm{O}+\mathrm{O}_{2}\right)$ is assumed to be about 0.5 at this point. As this ratio decreased and the water vapor content increased, water vapor began diffusing through the hydroxide layer and reacting with the metallic sodium to form hydrogen. This process occurred in addition to those reactions which occurred in the nozzle vent region. The oxygen, in forming a semi-protective oxide layer on the surface of the deposited metallic sodium, provided a delaying mechanism for the sodium-water vapor reactions. Only when the water vapor concentration was high enough to form liquid hydroxide and then diffuse through the hydroxide to the sodium could hydrogen be formed.

\subsection{Test Series F - Effects of Jet Velocity}

The objective of Test Series $F$ was to determine the effect of flow velocity on ignition of hydrogen-nitrogen jets. During Test Series B, Taminar jets at low velocities were ignited inside the secondary vessel. Test Series F used turbulent jets for comparison.

For Test Series $F$, the secondary vessel was removed, allowing the hydrogen jet to issue into the cell atmosphere. To increase the jet velocity, the nozzle diameter was decreased to 0.18 -inch $(4.6-\mathrm{mm})$ ID and the gas flow through the nozzle increased to 2.0 SCFM $(57 \mathrm{l} / \mathrm{min}$ at STP). The primary vessel and diaphragm were heated to temperatures varying from 70 to $1400^{\circ} \mathrm{F}\left(21\right.$ to $\left.760^{\circ} \mathrm{C}\right)$. The hydrogen jet, consisting of 75 percent hydrogen and 25 percent nitrogen, issued into the 70 to $80^{\circ} \mathrm{F}\left(21\right.$ to $\left.27^{\circ} \mathrm{C}\right)$ air atmosphere of the ventilated enclosure cel1. The velocities and Reynolds numbers for Test Series $B$ and $F$ 
are given in Table 5 as a function of the primary gas temperature. The test conditions are summarized in Table 2. The critical Reynolds number for conversion from laminar to turbulent flow is 2100 to 2300. (3) Table 5 shows that Test Series $B$ was in the laminar regime, whereas Test Series $F$ was turbulent, based on nozzle diameter as the characteristic dimension.

As in Test Series $B$, the ignition data were obtained by holding the primary gas hydrogen concentration, flow rate, and temperature constant while varying the sodium vapor/aerosol concentration flowing through the nozzle. The ignition of the hydrogen jet was determined by observation and correlated with the sodium concentration and primary gas temperature. The data are plotted in Figure 14. Higher sodium concentrations (up to $90 \mathrm{~g} / \mathrm{m}^{3}$ ) were possible with the higher primary flows, but no significant difference in hydrogen ignition was observed between the two test series.

A short color motion picture was made of the ignition process. The primary gas temperature was set at 400 and $900^{\circ} \mathrm{F}\left(204\right.$ and $\left.482^{\circ} \mathrm{C}\right)$. Three film speeds were used: normal, 250 frames per second, and 500 frames per second. The film illustrated that repeatable ignition initiated either at the middle of the flame height or at the nozzle exit. The sodium released from the nozzle was in three forms: (1) a vapor burning above the nozzle with a dull luminescence; (2) burning particles spraying out of the nozzle, and (3) liquid sodium running out of the nozzle forming a burning ring around the nozzle.

\subsection{ACKNOWLEDGMENTS}

The authors wish to express sincere gratitude to those individuals whose continuous efforts, understanding, and dedication helped complete the test program. R. E. Menard, G. W. Walker and B. B. Bentley were the technicians responsible for operating and maintaining the test equipment and facilities. Guidance in test definition and analytical support were provided by G. R. Armstrong, D. D. Stepnewski, R. D. Peak, G. O. Hultgren, and A. K. Postma. L. D. Muhlestein provided managerial support for the testing program. R. F. Keough and D. L. Baldwin performed the necessary chemical anaiysis. Clerical and secretarial duties were performed by B. K. Frederick. 
TABLE 5

JET VELOCITIES AND REYNOLDS NUMBERS

FOR 75\% HYDROGEN-25\% NITROGEN JETS

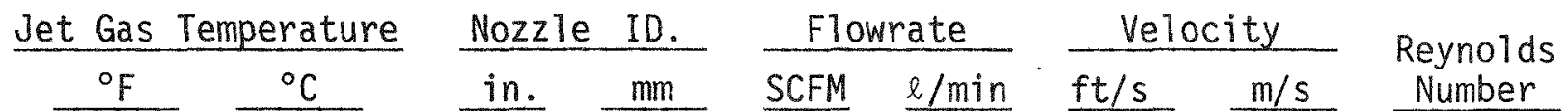

TEST SERIES B

$\begin{array}{rrrrrrrrr}100 & 38 & 0.43 & 10.90 & 0.2 & 5.7 & 3.4 & 1.04 & 309 \\ 500 & 260 & 0.43 & 10.90 & 0.2 & 5.7 & 5.9 & 1.80 & 234 \\ 1000 & 538 & 0.43 & 10.90 & 0.2 & 5.7 & 9.0 & 2.70 & 177 \\ 1500 & 816 & 0.43 & 10.90 & 0.2 & 5.7 & 12.1 & 3.70 & 147\end{array}$

TEST SERIES $F$

$\begin{array}{rrrrrrrrr}100 & 38 & 0.18 & 4.57 & 2.0 & 57.0 & 199.0 & 60.00 & 7567 \\ 500 & 260 & 0.18 & 4.57 & 2.0 & 57.0 & 342.0 & 104.00 & 5736 \\ 1000 & 538 & 0.18 & 4.57 & 2.0 & 57.0 & 520.0 & 158.00 & 4293 \\ 1500 & 816 & 0.18 & 4.57 & 2.0 & 57.0 & 698.0 & 210.00 & 3555\end{array}$




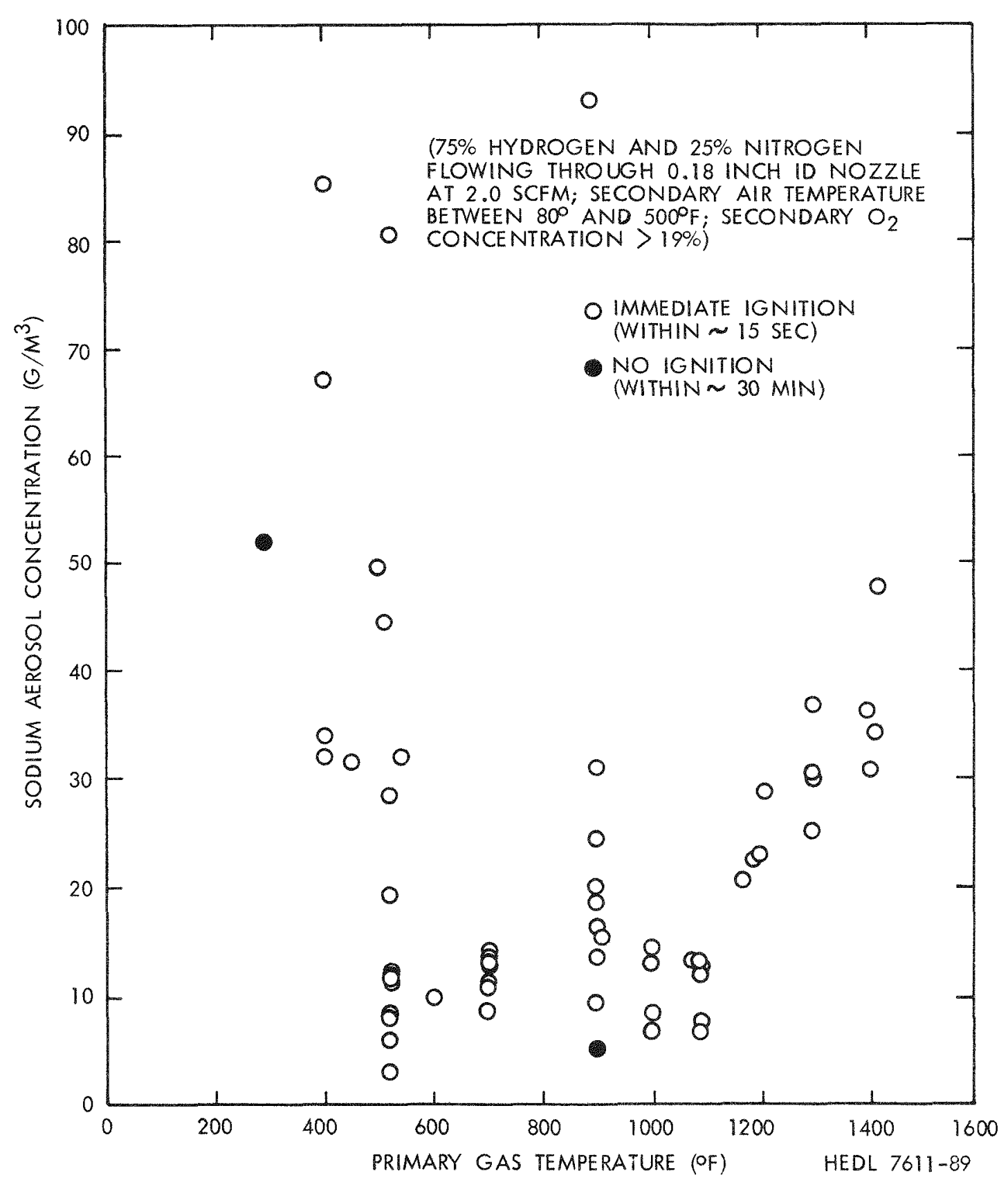

FIGURE 14. Ignition Characteristics of a Turbulent Hydrogen-Sodium Jet. 


\subsection{REFERENCES}

1. R. K. Hilliard and J. M. Yatabe. FFTF Secondary Sodium Fire Protection System Test F1, HEDL-TME 73-48, Hanford Engineering Development Laboratory, Apri1 1973.

2. John H. Perry, ed., Chemical Engineering Handbook, Third Edition (McGraw-Hill Book Co., New York, 1950), p. 1868.

3. Ibid, p. 383. 
APPENDIX A TEST EQUIPMENT

FIGURE $A-1$. TABLE A-1. FIGURE A-2. FIGURE A-3. FIGURE A-4. FIGURE A-5. FIGURE A-6.
Schematic of Heater and Thermocouple Locations Thermocouple Locations

One-Quarter Front View of Completed Installation of Test Vessels

External Sodium Vapor/Aerosol Generator

Schematic of Steam Generator

Schematic of Gas Humidifier and Drier

Schematic of 0.43-Inch ID Nozzle and Thermocouple Arrangement 


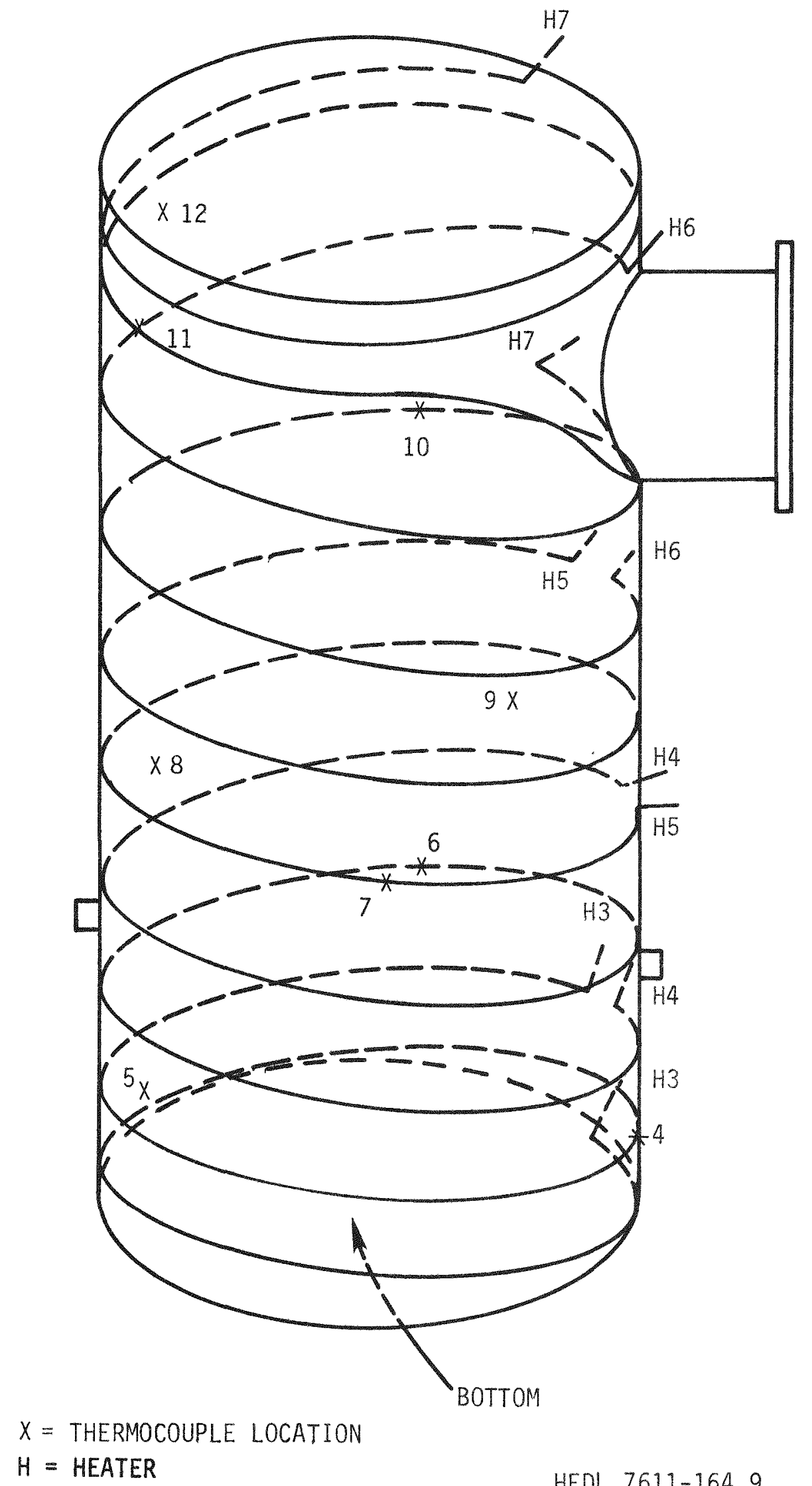

HEDL 7611-164.9

FIGURE A-1a. Schematic of Heater and Thermocouple Locations - Primary Vessel Walls. 


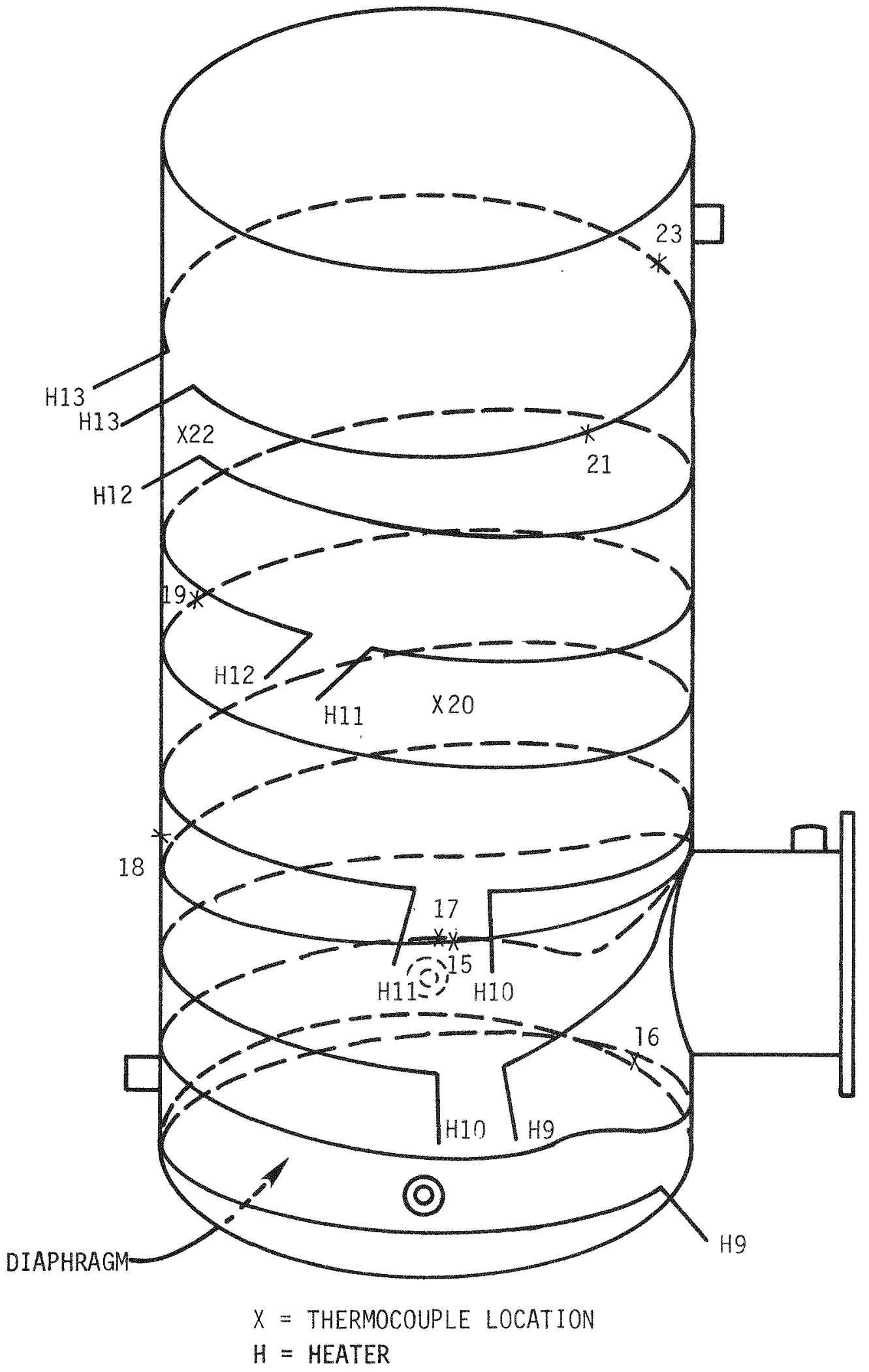

HEDL 7611-164.11

FIGURE A-1b. Schematic of Heater and Thermocouple Locations Secondary Vessel Walls. 

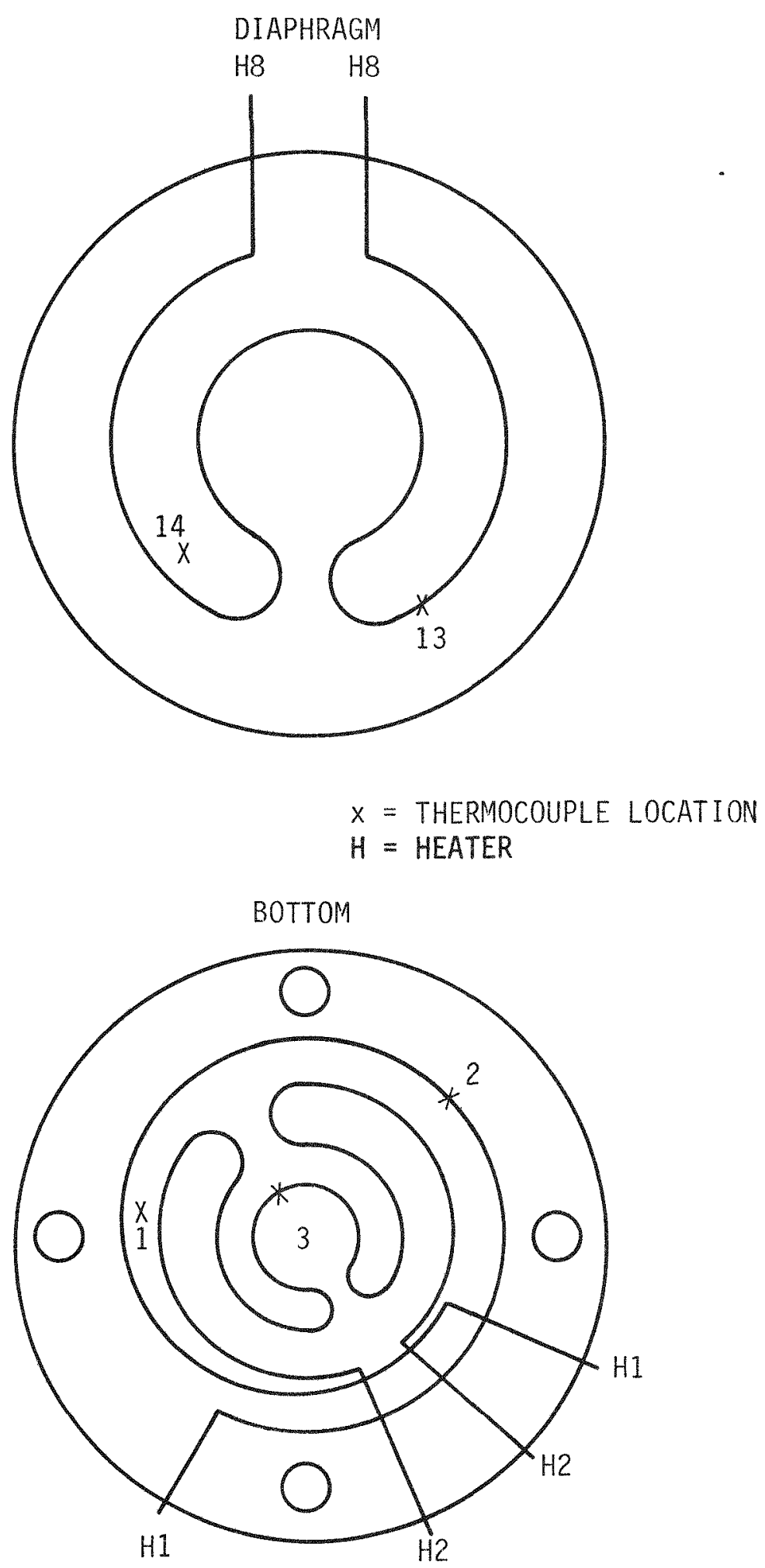

FIGURE A-1C. Schematic of Heater and Thermocouple Locations Bottom of Primary Vessel and Diaphragm. 
TABLE A-1

THERMOCOUPLE LOCATIONS

\begin{tabular}{|c|c|c|}
\hline $\begin{array}{c}\text { Thermocouple } \\
\text { Number }\end{array}$ & $\begin{array}{l}\text { Recorder } \\
\text { Point }\end{array}$ & Location Description \\
\hline $\begin{array}{l}1 \\
2^{*} \\
3 \\
4^{*} \\
5\end{array}$ & $\begin{array}{l}\text { TRC }-1 \\
\overline{\text { TRC }-}-\overline{3} \\
=-\bar{T} \\
\text { TRC }-\overline{5}\end{array}$ & $\begin{array}{l}\text { Bottom of } P V \text { between } H 7 \text { and } H 2 \text {, outside } \\
\text { of vesse } 1 \\
\text { Bottom of } P V \text { on } H 1 \\
\text { Bottom of } P V \text { on } H 2 \\
\text { PV on } H 3 \\
\text { PV between } H 3 \text { and } H 4 \text {, outside of vessel }\end{array}$ \\
\hline $\begin{array}{r}6 \\
7 \\
8 \\
9 \\
10\end{array}$ & $\begin{array}{l}\text { TRC }-6 \\
\text { TRC }-7 \\
\text { TRC }-8 \\
\text { TRC }-9 \\
\text { TRC }-10\end{array}$ & $\begin{array}{l}\text { PV on } H 4 \\
\text { PV on } H 5 \\
\text { PV between } H 4 \text { and } H 5 \text {, outside of vessel } \\
\text { PV between } H 5 \text { and } H 6 \text {, outside of vessel } \\
\text { PV on } H 6\end{array}$ \\
\hline $\begin{array}{l}17^{\star} \\
12 \\
13^{*} \\
14 \\
15\end{array}$ & $\begin{array}{l}\overline{\text { TRC }}-\overline{-12} \\
-\overline{-}- \\
\text { TRE-2 } \\
\text { TRE-3 }\end{array}$ & $\begin{array}{l}\text { PV on } H 7 \\
\text { PV between } H 6 \text { and } H 7 \text {, outside of vessel } \\
\text { Diaphragm on } H 8 \\
\text { Diaphragm on topside surface } \\
\text { SV on } H 9\end{array}$ \\
\hline $\begin{array}{l}16 \\
17^{*} \\
18 \\
19 * \\
20\end{array}$ & $\begin{array}{l}\text { TRE }-4 \\
\overline{\text { TRE }-\overline{6}} \\
\overline{-}-\overline{-} \\
\text { TRE-8 }\end{array}$ & $\begin{array}{l}\text { Near } 16^{\prime \prime} \text { flange on outside of SV wall } \\
\text { SV on HIO } \\
\text { SV between HIO and } H 17 \text {, outside of vessel } \\
\text { SV on HII } \\
\text { Mid-section of SV on outside of vessel }\end{array}$ \\
\hline $\begin{array}{l}27 \\
22 \\
23 \\
24 \\
25\end{array}$ & $\begin{array}{l}\text { TRE }-9 \\
\text { TRE }-10 \\
\text { TRE }-11 \\
\text { TRF- } 1 \\
\text { TRD-RD }\end{array}$ & $\begin{array}{l}\text { SV on } H 12 \\
\text { SV between } H 12 \text { and } H 13 \text {, outside of vesse } 1 \\
\text { SV on HI3 } \\
0.25 \text { inches above vent nozzle } \\
0.75 \text { inches above vent nozzle }\end{array}$ \\
\hline $\begin{array}{l}26 \\
27 \\
28 \\
29 \\
30\end{array}$ & $\begin{array}{l}\text { TRF }-3 \\
\text { TRF-4 } \\
\text { TRF-5 } \\
\text { TRF }-6 \\
\text { TRG-1 }\end{array}$ & $\begin{array}{l}1.5 \text { inches above vent nozzle } \\
2.5 \text { inches above vent nozzle } \\
3.5 \text { inches above vent nozzle } \\
4.5 \text { inches above vent nozzle } \\
\text { Gas space near outlet of PV gas supply line }\end{array}$ \\
\hline $\begin{array}{l}31 \\
32 \\
33 \\
34 \\
35\end{array}$ & $\begin{array}{l}\text { TRG-2 } \\
\text { TRG-3 } \\
\text { TRG-4 } \\
\text { TRG-5 } \\
\text { TRG-6 }\end{array}$ & $\begin{array}{l}\text { Near PV gas and smoke sample inlets } \\
\text { Gas space near outlet of SV gas supply line } \\
\text { Near SV smoke sample inlet } \\
\text { Near SV gas sample inlet } \\
1.0 \text { inches below SV vent pipe outlet }\end{array}$ \\
\hline $\begin{array}{l}36 \\
37 \\
38 \\
39 \\
40 *\end{array}$ & $\begin{array}{l}\text { TRG-7 } \\
\text { TRG-8 } \\
\text { TRD-BL } \\
\text { TRG-9 } \\
---\end{array}$ & $\begin{array}{l}\text { 1.0 inches above SV vent pipe outlet } \\
4.0 \text { inches above SV vent pipe outlet } \\
0.5 \text { inches below diaphragm nozzle coupling } \\
\text { Internal sodium pot located in sodium } \\
\text { PV gas supply line, outside of tube }\end{array}$ \\
\hline $\begin{array}{l}41 * \\
42^{\star} \\
43 \\
44 \\
45\end{array}$ & $\begin{array}{l}--\overline{-} \\
--\overline{-} \\
\text { TRG-9 } \\
\text { TRG-10 } \\
\text { TRG-11 }\end{array}$ & $\begin{array}{l}\text { SV gas supply line, outside of tube } \\
\text { Internal sodium pot, on outside wall } \\
\text { External sodium pot, in sodium } \\
\text { External sodium pot, on outside wall } \\
\text { Humidifier exit, centerline }\end{array}$ \\
\hline
\end{tabular}




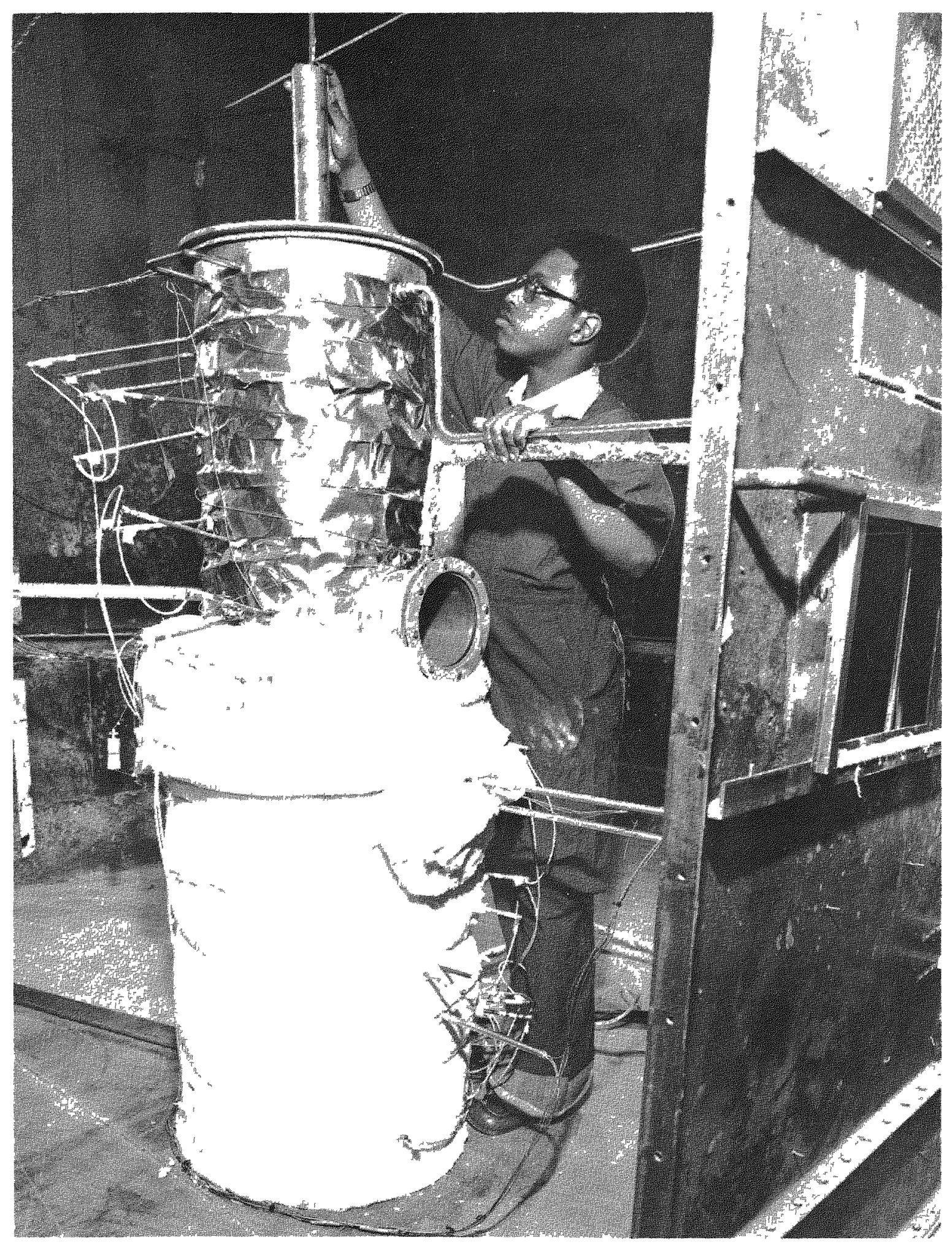

FIGURE A-2. One-Quarter Front View of Completed Installation of Test Vessels. 


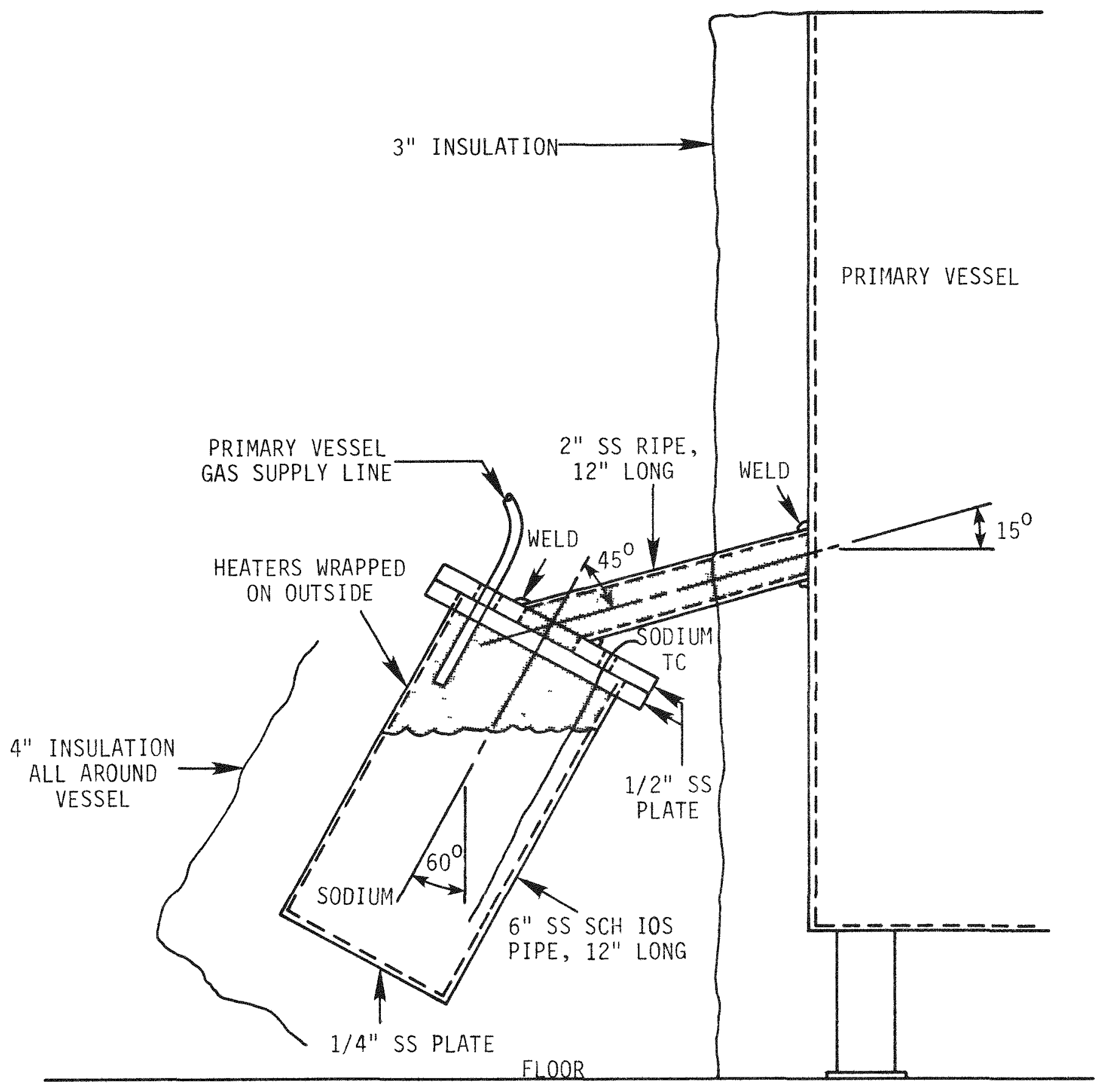

HEDL $7611-164.6$

FIGURE A-3. External Sodium Vapor/Aerosol Generator. 


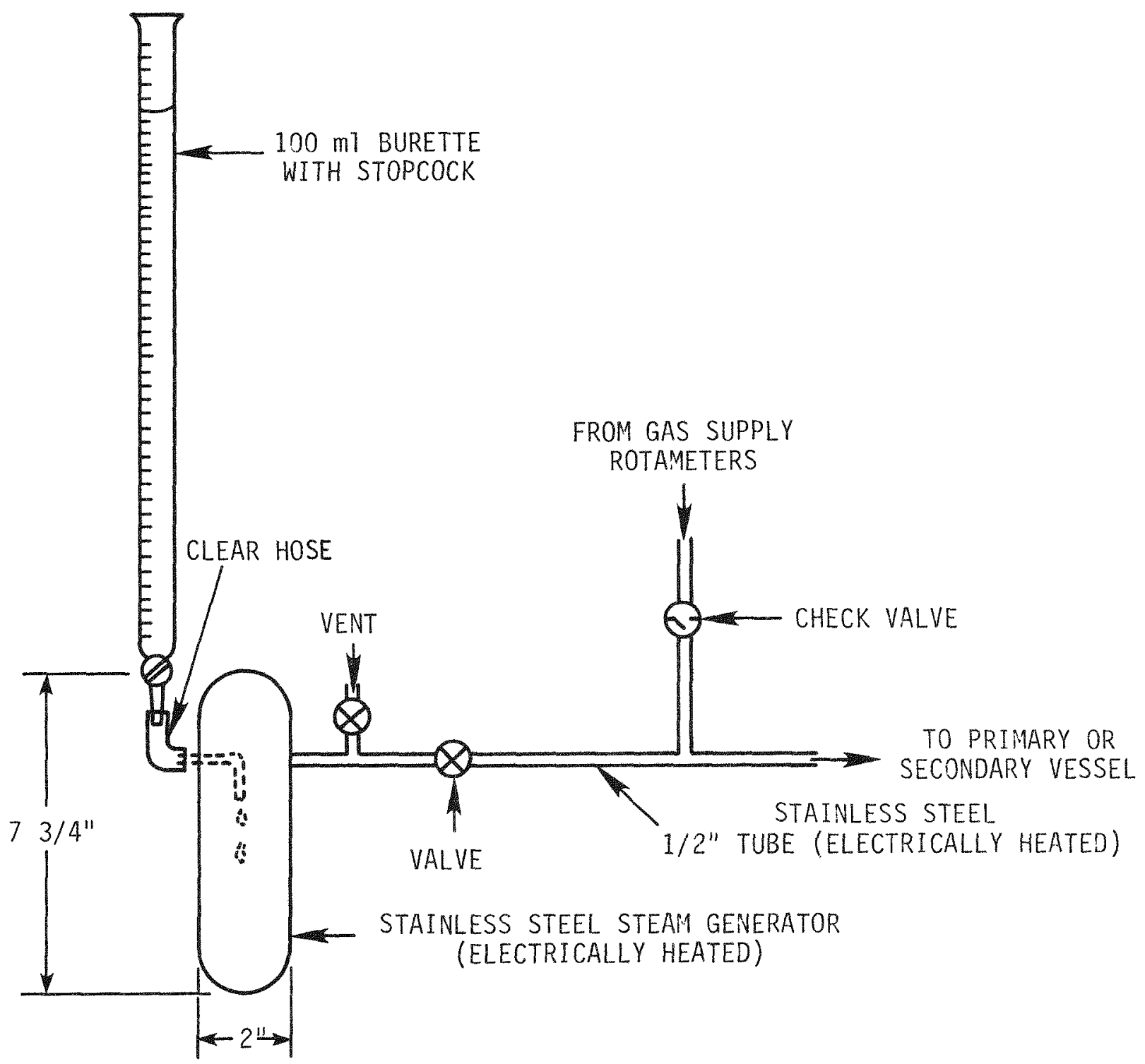

FIGURE A-4. Schematic of Steam Generator.

$$
\text { A- } 8
$$




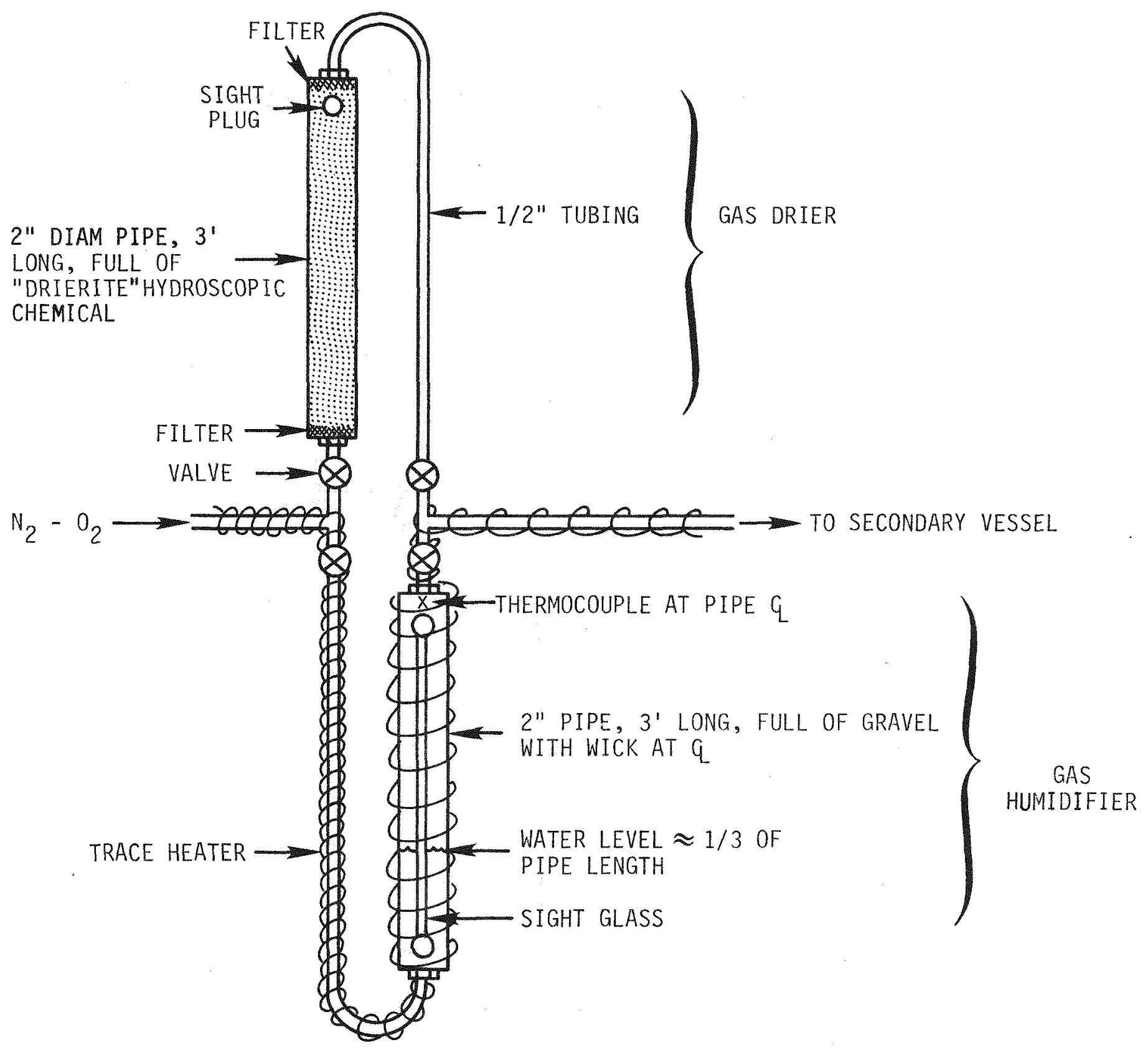

FIGURE A-5. Schematic of Gas Humidifier and Drier. 


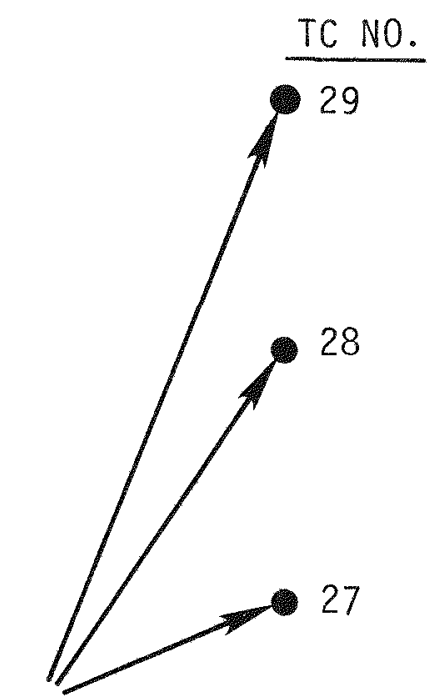

THERMOCOUPLE
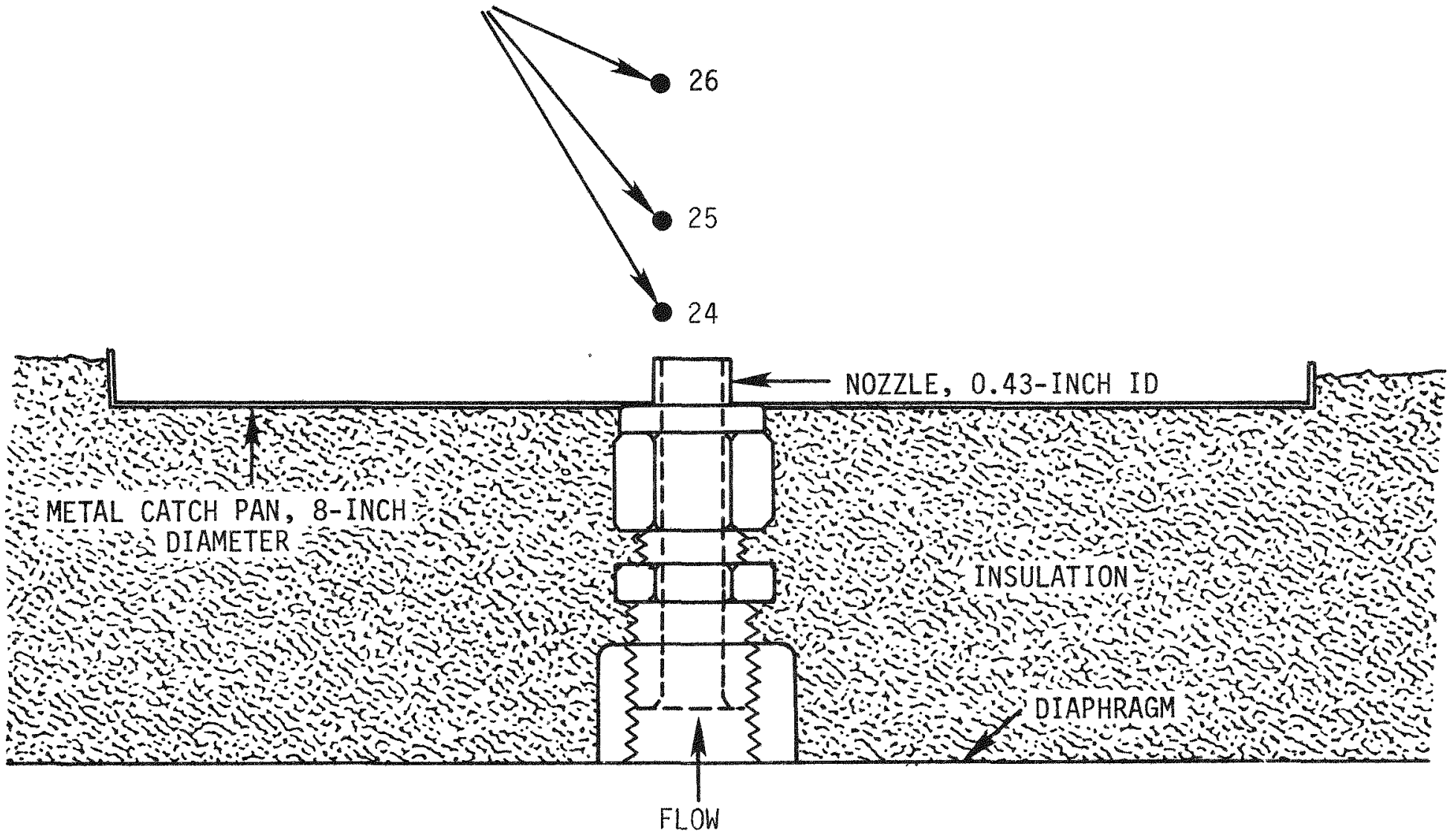

(Actual Size)

HEDL $7611-164.10$

FIGURE A-6. Schematic of 0.43-Inch ID Nozzle and Thermocouple Arrangement. 


\section{APPENDIX B \\ SCOPING TESTS RESULTS}

FIGURE B-1. Hydrogen Ignition Percentage Determination by Temperature Method

FIGURE B-2. Hydrogen Ignition Percentage Determination by Secondary Hydrogen Method

FIGURE B-3. Effects of Nozzle Diameter on Hydrogen Ignition 


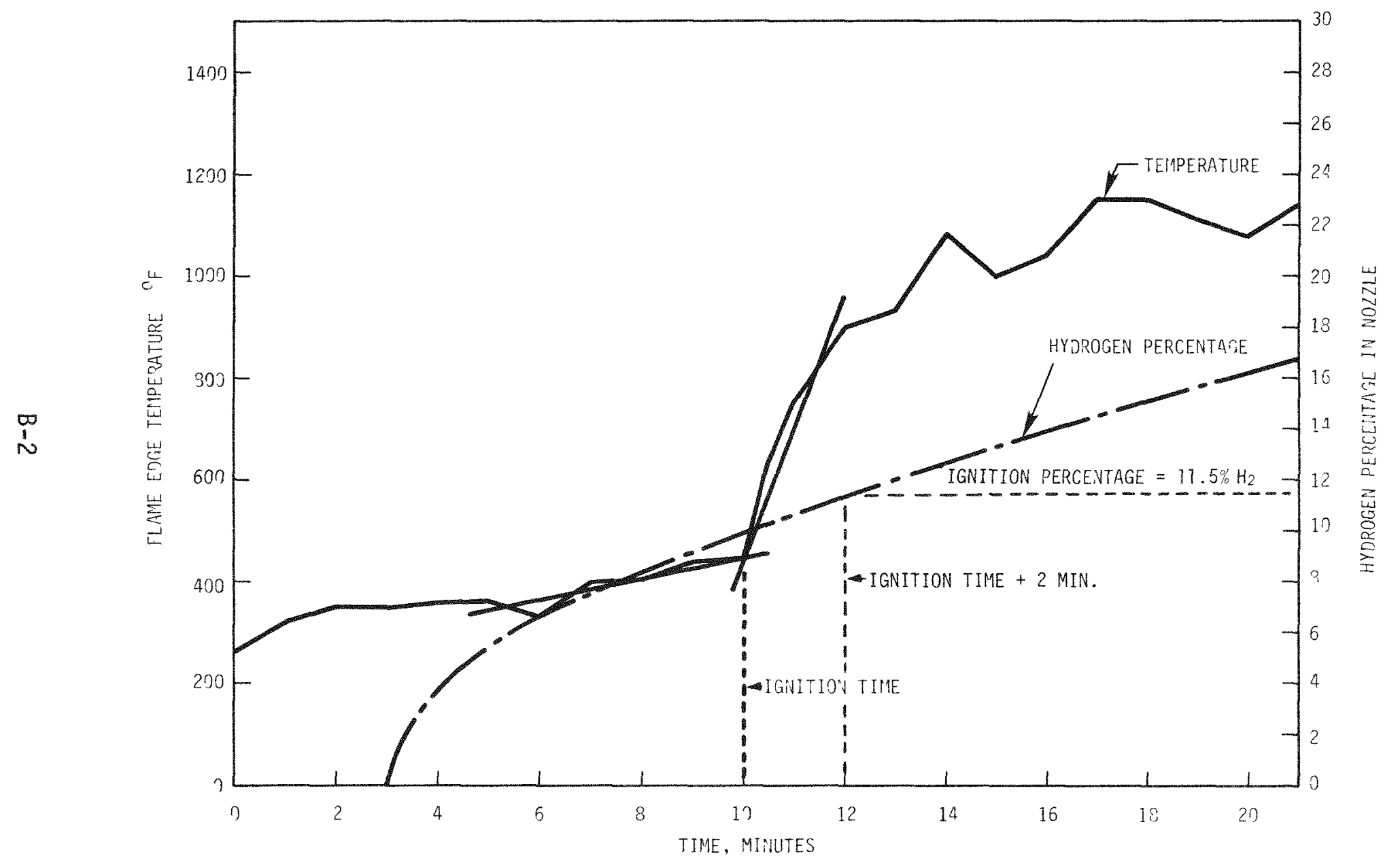

FIGURE B-1. Hydrogen Ignition Percentage Determination by Temperature Method. 


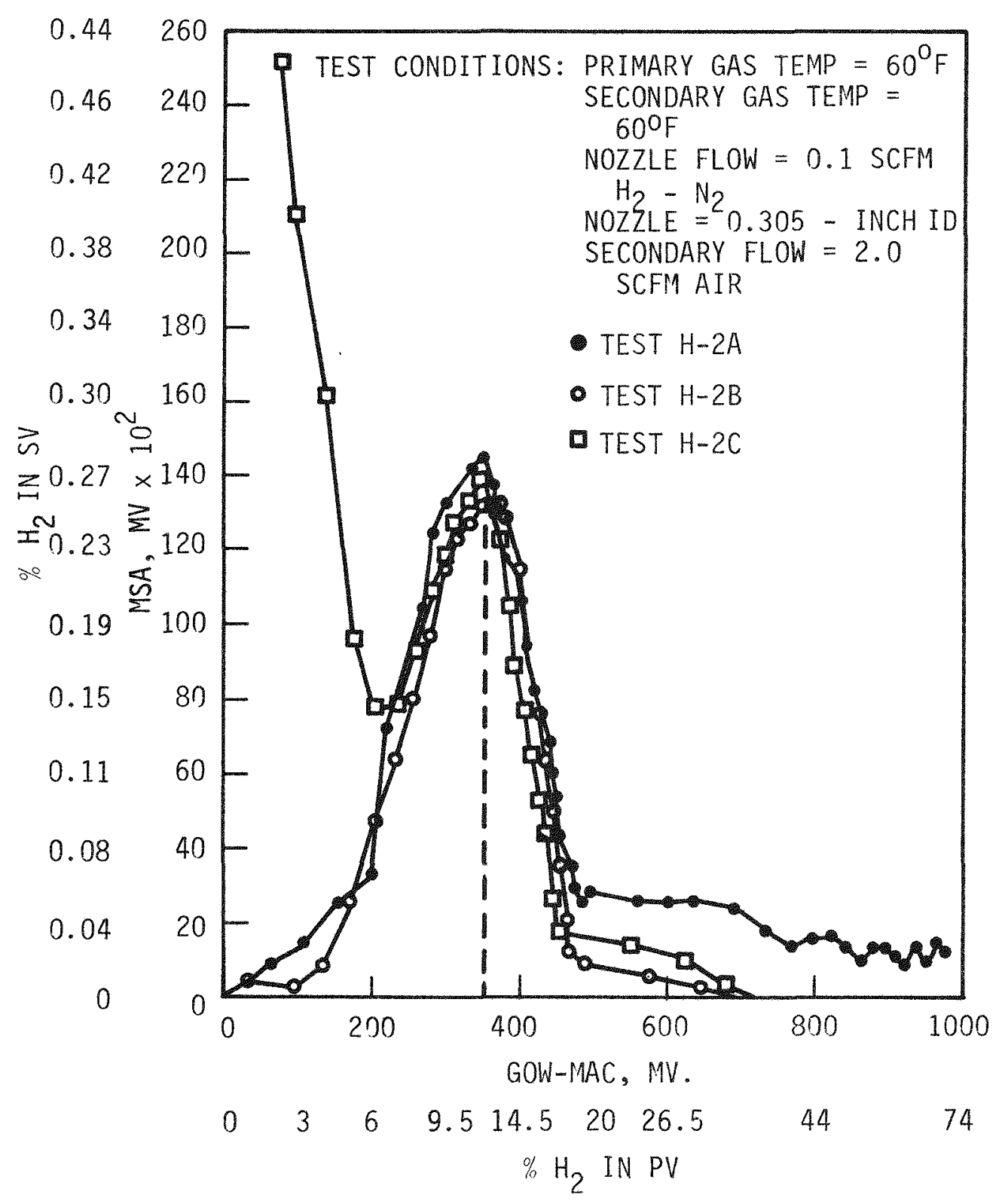

FIGURE B-2. Hydrogen Ignition Percentage Determination by Secondary Hydrogen Method. 


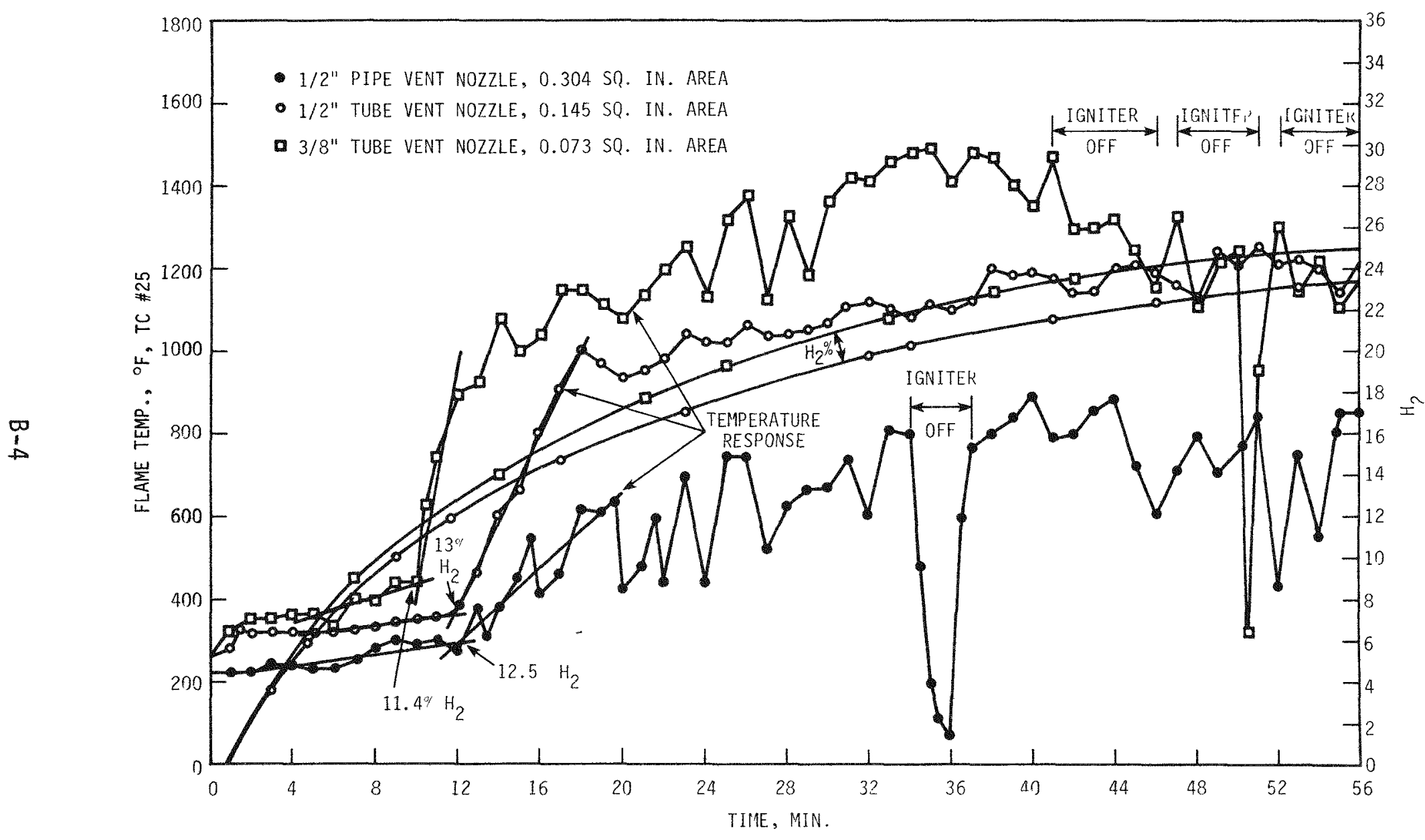

FIGURE B-3. Effects of Nozzle Diameter on Hydrogen Ignition. 